\title{
THE INFLUENCE OF DISCOURSES OF VULNERABILITY AND RESILIENCY ON CLIMATE CHANGE MIGRANTS' AGENCY: 'MIGRATION WITH DIGNITY' IN KIRIBATI
}

$$
\text { by }
$$

Tearney McDermott, BA (Honours), Queen's University, 2013

\author{
A Major Research Paper \\ presented to Ryerson University \\ in partial fulfillment of the requirements for the degree of \\ Master of Arts \\ in the Program of \\ Immigration and Settlement Studies
}

Toronto, Ontario, Canada, 2016

(C) Tearney McDermott 2016 


\section{AUTHOR'S DECLARATION FOR ELECTRONIC SUBMISSION OF A MAJOR RESEARCH PAPER (MRP)}

I hereby declare that I am the sole author of this Major Research Paper. This is a true copy of the $\mathrm{MRP}$, including any required final revisions, as accepted by my examiners.

I authorize Ryerson University to lend this MRP to other institutions or individuals for the purpose of scholarly research.

I further authorize Ryerson University to reproduce this paper by photocopying or by other means, in total or in part, at the request of other institutions or individuals for the purpose of scholarly research.

I understand that my MRP may be made electronically available to the public.

Tearney McDermott 


\title{
THE INFLUENCE OF DISCOURSES OF VULNERABILITY AND RESILIENCY ON CLIMATE CHANGE MIGRANTS' AGENCY: 'MIGRATION WITH DIGNITY' IN KIRIBATI
}

Tearney McDermott

Master of Arts, 2016

Immigration and Settlement Studies

Ryerson University

\begin{abstract}
This research paper presents a critical review of scholarly and policy literature discussing the relationship between climate change and migration. Focusing specifically on Small Island Developing States (SIDS), the climate change discourses of vulnerability and resiliency as they commonly operate are explored. A case study of Kiribati - a low-lying SIDS in the Pacific - is used to illustrate the complexities of climate change and the migration decisions of populations presently experiencing climate change. A discourse analysis focusing on how different stakeholders' understandings of Kiribati as vulnerable and resilient influence the agency and migration decisions of the people of Kiribati is conducted. This research utilizes concepts from climate justice theoretical literature as a framework for understanding vulnerability, resiliency, and responses to climate change.
\end{abstract}

Key words:

Climate change; migration; vulnerability; resiliency; Small Island Developing States; Kiribati 


\section{ACKNOWLEDGEMENTS}

Many thanks go out to my supervisor, Dr. Cheryl Teelucksingh. I have benefitted immensely from her thorough and thoughtful criticism of my work over the past several months. I am also grateful to my colleague, Zain Shah, whose energy and optimism served as constant inspiration throughout the writing process. Finally, I would like to thank my family and Colin Richards for their continual patience and support. 


\section{LIST OF ABBREVIATIONS}

GoK............Government of Kiribati

KAP............Kiribati Adaptation Plan

SIDS...........Small Island Developing State(s) 


\section{TABLE OF CONTENTS}

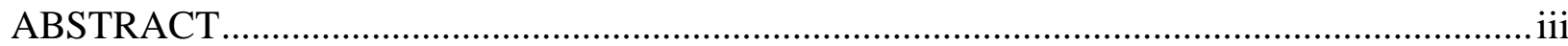

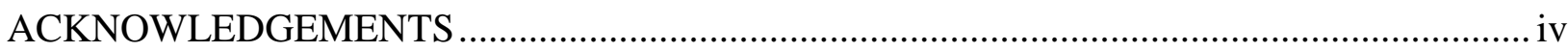

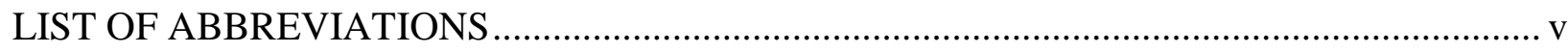

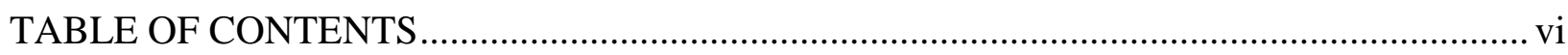

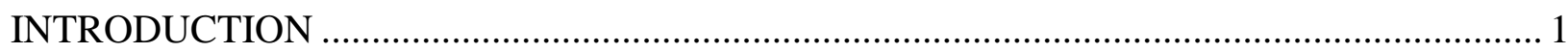

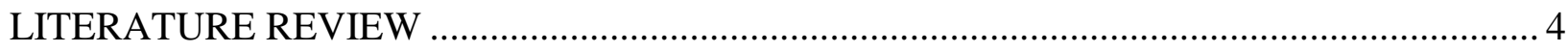

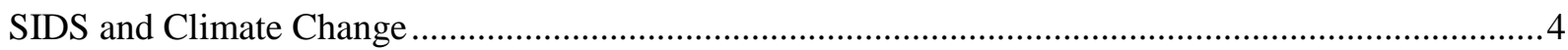

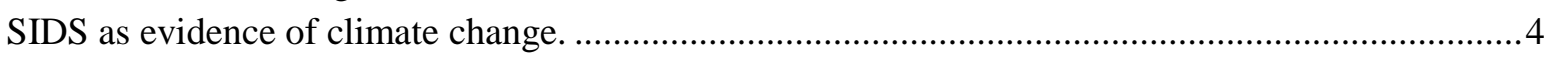

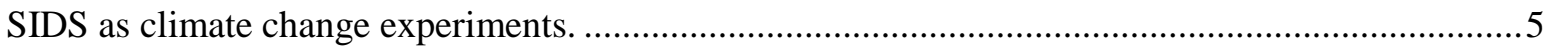

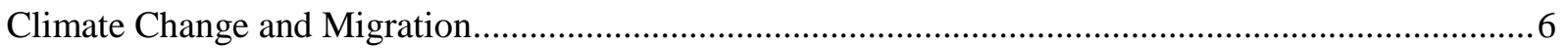

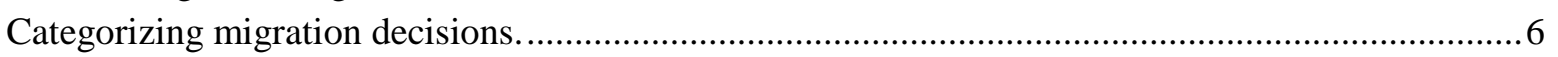

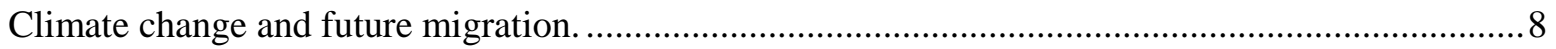

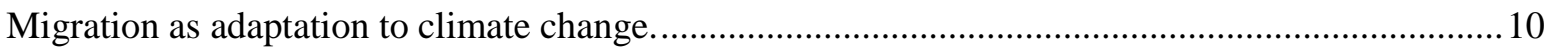

Climate change and migration from SIDS. ............................................................................. 11

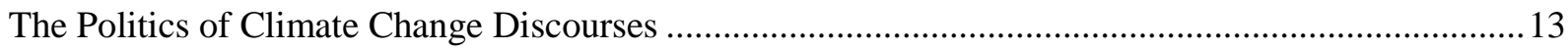

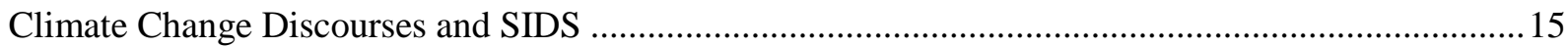

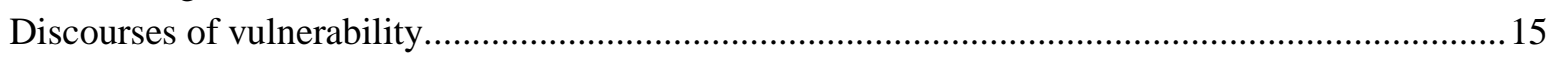

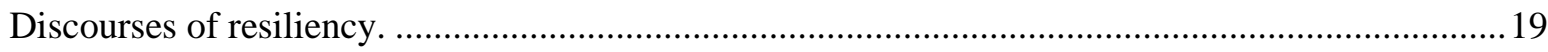

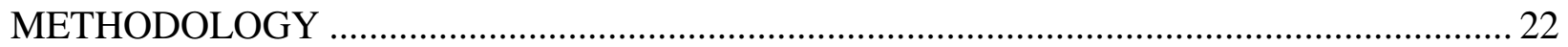

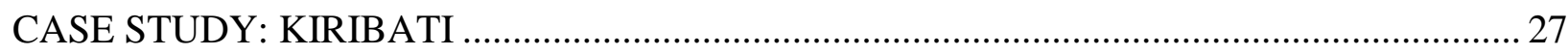

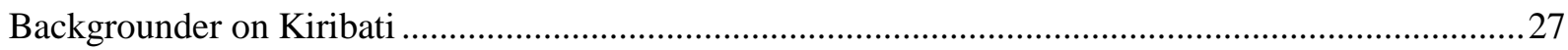

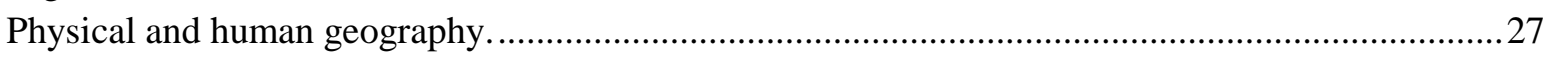

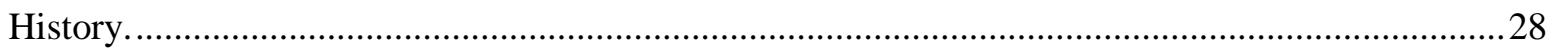

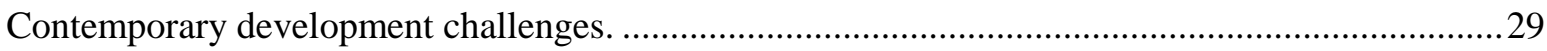

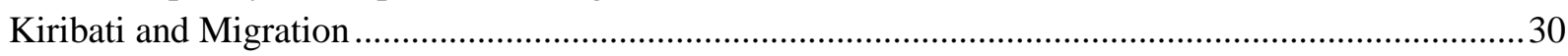

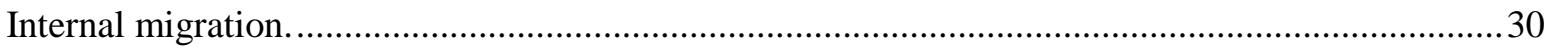

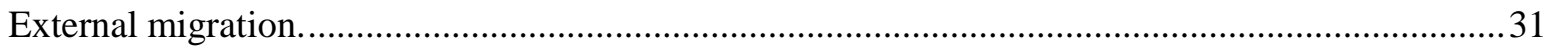

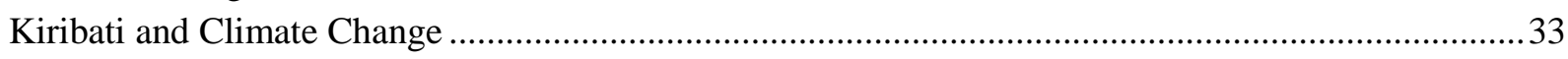

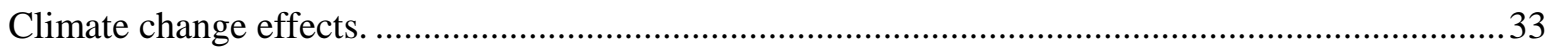

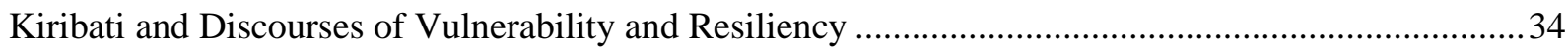

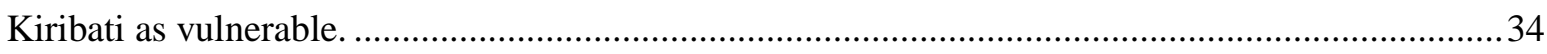

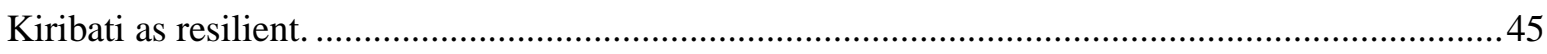

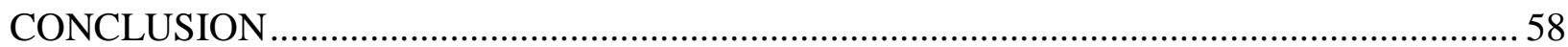

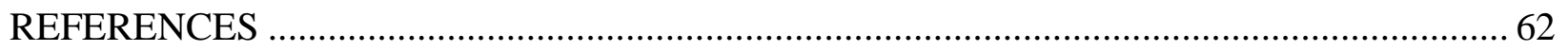




\section{INTRODUCTION}

Scientists have known about climate change for close to two hundred years (Farmer \& Cook, 2013; Bell, 2016), though the hazards of increasing atmospheric concentrations of greenhouse gases - and particularly humans' role in this increase - did not become clear until the 1960s (NASA, 2016). Since the 1980s, governments have been discussing strategies for managing climate change and its effects (Bodansky, 2001; Bell, 2016), yet thirty years on, climate change poses a sustained threat. The World Economic Forum's 2016 Global Risks Report distinguishes the "failure of climate change mitigation and adaptation" as the single most impactful risk to human livelihood faced now and in the foreseeable future (World Economic Forum, 2016, p. 6).

According to the United Nations High Commissioner for Refugees (2015), since 2008, approximately 22.5 million individuals have been displaced annually as a result of climate change; and in the Pacific region alone, environmental factors have influenced the relocation of at least eighty-six whole communities. Climate change is currently, and will for the foreseeable future continue to be, a significant driver of migration (Geddes, Adger, Arnell, Black \& Thomas, 2012; Fatorić, 2014; Adamo, 2016). There is agreement among governments that divestment in activities contributing to climate change will in due course become imperative for the security of all states - and not simply those currently producing climate change migrants (Paris Agreement, 2015). However, the current rate at which developed states seem most comfortable addressing climate change is discordant with the rate at which they would need to proceed if they were to prevent any further large-scale climate change migration (Edenhofer et al., 2014).

Against this backdrop, this research presents a case study of Kiribati-a low-lying SIDS in the Pacific whose densely populated capital, Tarawa, is projected to be fully submerged by 
$2050(\mathrm{Ni}, 2015)$. Kiribati is used to illustrate the complexities of climate change migration, and explore the implications of two climate change discourses commonly applied to SIDS vulnerability and resiliency - for a population presently exposed to climate change. Kiribati is particularly significant as representative of a population faced with what is currently a relatively unprecedented situation, but which may become the norm for many populations in the decades to come, in the absence of serious mobilization from the states actively contributing to climate change.

Concepts from climate justice theoretical literature are used in this research as a framework for understanding vulnerability, resiliency, and responses to climate change. In the past, climate change had been considered a purely environmental issue (Atapaltu, 2016), however, we have known for decades that humans' activities contribute directly to climate change, with about half of the cumulative anthropogenic carbon dioxide emissions since 1750 having been produced in the last forty years (Edenhofer et al., 2014). This increasingly accelerated growth in emissions has accompanied an escalation in human industrial activity, with about forty percent of these emissions remaining in the atmosphere, and the rest settling in the oceans and soils (Edenhofer et al., 2014). The associated changes in global climate patterns have not been experienced equally around the world (Melillo, Richmond \& Yohe, 2014).

Kiribati and other SIDS collectively produce extremely low levels of emissions while simultaneously experiencing significant effects of climate change (Arnall, Kothari \& Kelman, 2014), making their circumstances disproportionately unjust, and their capacities for adaptation particularly linked to international conceptions of their vulnerability and resiliency. Many SIDS have been very vocal about their situation, using moral and political suasion in hopes of spurring meaningful climate action - though responses from developed states have thus far been largely 
disappointing (Dreher \& Voyer, 2015). A central theme of climate justice is the recognition that those whose experiences are affected the most by climate change are those who have contributed the least to the problem (Alabi, 2016; Atapattu, 2016). The politics related to climate justice critique unequal power dynamics globally, as well as globalization, capitalism, and neoliberalism (Alabi, 2016). These mechanisms work to reinforce the vulnerability of those who ultimately bear the burden of climate change, and differentiated vulnerability to climate change is therefore viewed as an unnatural product of social and economic inequality, raising serious ethical and political issues. Climate justice links notions of environmental protection, human rights, and development (Atapattu, 2016), and stresses that recognizing the unjust roots of climate change is imperative to developing effective climate change policy.

A review of the relevant scholarly and policy literature discussing the relationship between climate change and migration from SIDS follows below. 


\section{LITERATURE REVIEW}

In order to provide context to the case study of Kiribati presented in the next section, a critical review of scholarly and policy literature discussing the relationship between climate change and migration has been conducted. Focusing specifically on SIDS, the influence of discourses of vulnerability and resiliency on responses to climate change, with particular attention to migration within and from SIDS, is explored.

\section{SIDS and Climate Change}

\section{SIDS as evidence of climate change.}

Though, in scientific communities, the debate about whether or not humans are responsible for changing the climate is altogether settled - with ninety-seven percent of active publishing climate scientists believing that anthropogenic climate change is real and happening now (Cook et al., 2013; Maibach, Myers \& Leiserowitz, 2014) - there is no such consensus in the public sphere (Pölzler, 2015). In some countries, such as the United States - the second largest producer of carbon dioxide emissions in the world (Pölzler, 2015) - information about climate change is openly available, yet climate change remains a contested issue (Maibach, Myers \& Leiserowitz, 2014), and climate concern is surprisingly low (Angus Reid, 2011). Researchers point to the tendency of popular media reporting on climate change to ascribe equal weight to scientifically discredited views out of a desire for "balance in reporting" (Boykoff \& Boykoff, 2004; The David Suzuki Foundation, 2014) as creating the illusion that scientists are still debating the reality of climate change, when in fact they are not. Additionally, there is welldocumented evidence of stakeholders from coal and fossil fuel companies and industry-funded lobby groups exerting pressure on scientists (Dunlap \& McCright, 2011) and politicians (Hickman, 2013) to reposition climate change as just one environmental theory among many 
(Dunlap \& McCright, 2011; The David Suzuki Foundation, 2014). Against this backdrop of public confusion and skepticism of climate change science, many have become fixated on producing "evidence" of climate change (Cameron, 2011).

Islands occupy a unique place in popular imagination as representing the most immediate effects of climate change (Barnett \& Campbell, 2010). As a result, SIDS and their communities are regularly appropriated by researchers, media, politicians, and environmental nongovernmental organizations, who push various agendas as confirmation of the reality, fallacy, urgency, triviality, etc. of climate change (Dreher \& Voyer, 2015). These portrayals often see the significant differences between SIDS in terms of size, population, local cultures, governance, infrastructure, development, and resources ignored, and the conditions of one SIDS used to make simplified generalizations about all SIDS facing climate change (Farbotko \& Lazrus, 2012). These discourses have the effect of deciding which attitudes and approaches to climate change are appropriate and which are not, and are considered harmful to the agency and individuality of SIDS (Farbotko \& Lazrus, 2012).

\section{SIDS as climate change experiments.}

The 'canary in the coal mine' trope is one commonly associated with SIDS in the context of climate change (UNFCCC, 2005). As among the first states experiencing critical changes, SIDS serve as an advanced warning to other states of the dangers and breadth of future climate change (UNFCCC, 2005). Imagery of climate change impacts in SIDS is often used for its "instrumental shock value" to encourage climate concern and action lest distant realities become local realities (Dreher \& Voyer, 2015, p. 69). For the same reason, researchers take advantage of the rich opportunities offered by SIDS for studying the nature of climate change to mitigate future impacts (Wells, 2014). Though it essentially requires SIDS being used as 'litmus tests' 
for the rest of the planet's safety, SIDS themselves have often been the initial instigators of these research relationships in an effort to draw attention to their situations (Eman, 2015).

The treatment of SIDS communities as laboratories for the greater good is not without precedent, as SIDS have historically been exposed to high levels of radiation during the testing of nuclear bombs (Wells, 2014). Additionally, the concentration of research into mitigation and adaptation strategies is ultimately decided externally, and driven by questions of what will be effective for future states experiencing these effects, rather than tailored to the specific concerns and experiences of SIDS communities. As a result, there is an implicit power imbalance between developed nations and less developed nations, which only serves to further marginalize populations already disproportionately affected by climate change (Barnett \& Campbell, 2010; Farbotko \& Lazrus, 2012). The focus of research on SIDS has also been criticized for perpetuating a "pseudo-procrastinating rationality" for general climate inaction in states geographically removed from SIDS, since climate change becomes understood as only currently occurring on remote islands (Wells, 2014, n.p.).

\section{Climate Change and Migration}

\section{Categorizing migration decisions.}

Despite significant evidence throughout history of mass population movements being linked to climatic variability and climate events (Fatorić, 2014), as well as projections that carbon emissions and the associated changes in global climate patterns will only increase, there is very little literature explicitly advocating migration as a climate change adaptation strategy (Fatorić, 2014; Porter, 2015). In relation to climate change, migration is most often discussed as a consequence - an outcome when all climate change adaptation efforts have failed (Tacoli, 2009; Porter, 2015). Certainly, in many cases, migration is undesirable, and especially so when 
migrants' agency is removed such that they are not in control of their circumstances and their migration decisions are therefore inhibited (Tacoli, 2009). For this reason, some scholars prefer to visualize migration as occurring along a continuum of 'voluntary' and 'forced' extremes (Hugo, 1996).

Migration decisions made to avoid immediate, life-threatening effects of climate change are considered to be 'forced', while migration decisions made in an effort to avoid future effects of climate change are considered to be 'voluntary' (Renaud, Dun, Warner \& Bogardi, 2011). Critics of this continuum argue that assessing the agency of migrants is inherently difficult, since an ostensibly voluntary decision to migrate, when prompted by uncontrollable externalities such as climate change - be they immediate or future threats - is also arguably forced (Yarris \& Castañeda, 2015). Others argue that the relationship between migration and climate change is much more complex, with environmental changes such as climatic variability affecting migration decisions only after being "filtered through the local socio-economic context", making it both difficult and naive to attribute migration directly to climate change (Upadhyay, Kelman, Lingaraj, Mishra, Shreve \& Stojanov, 2015, p. 399).

The varying opinions of climate change and its connections to migration have made it difficult for the international community to collectively settle on one definition of climate change migration (Omeziri \& Gore, 2014). Identifying people as being displaced a result of climate change is challenging since climate change is rarely the only consideration affecting migration decisions (Omeziri \& Gore, 2014). Additionally, characterizing migration as being forced or voluntary is complex since migrants are still agents regardless of how limited their capacities for action may be. Though migrants may be embedded in particular social, political, or environmental situations, their decisions of why and when to move continue to be affected by 
their points of view and experiences (Turton, 2003). Therefore, while climate change migration is discussed throughout this research paper, the term is only used in reference to the fact that the migration in question has been influenced by climate change in some way, and it is acknowledged that there is no authoritative definition of this migration.

\section{Climate change and future migration.}

Due to the relatively high level of unpredictability surrounding the specific effects of climate change, there are inherent complexities in anticipating with any accuracy the impact of climate change on human migration (Resurreccion, 2016), and, by extension, considerable uncertainty about the number of migrants that climate change may produce (Wyman, 2013). Additionally, the limited data on migration flows within developing states' borders, where, at least initially, the majority of climate change migration is projected to occur, makes targeted policy recommendations difficult (Resurreccion, 2016). However, based on past migration trends, the Migration Policy Institute (2013) has forecasted paths by which climate change might affect future migration.

First, prolonged drying trends are expected to reduce livelihoods in certain areasparticularly communities based on subsistence agriculture. Migration has been a common response to longer-term droughts in the past, as exemplified by rural populations in Syria, Turkey, and Mexico (Migration Policy Institute, 2013). Second, rising sea levels are predicted to

render coastal and low-lying regions uninhabitable. Islands are likely to be the most affected by this trend, as their migration options are inherently limited by their relatively small spatial geography, their heavy economic and social reliance on coastal areas, and their distance from other countries. Already, flooding and erosion has caused internal migration within several island states (Migration Policy Institute, 2013). Third, the frequency and intensity of weather 
related natural hazards are expected to increase, disproportionately affecting poor populations in developing countries, though developed states will not be immune to these events, as evidenced by Hurricane Katrina in 2005 in the United States (Migration Policy Institute, 2013). Finally, competition over depleting natural resources is likely to exacerbate pressures typically contributing to social and political conflict (Migration Policy Institute, 2013). For instance, many scientists have argued that climate change has significantly shaped the Syrian Refugee Crisis (Dinshaw, 2015). In July 2015 at the Toronto Climate Summit of the Americas (TCSA), former U.S. Vice President Al Gore gave a speech articulating this view:

From 2006 to $2010[\ldots]$ a climate-related drought [...] destroyed 60 percent of their farms and killed 80 percent of their livestock and drove a million and a half climate refugees into the cities of Syria, where they collided with another million and a half refugees from the Iraq War. (Dinshaw, 2015, n.p.)

In a study of the effects of climate variability on conflict outcomes, Burke, Hsiang, and Miguel (2014) found that "deviations from moderate temperatures and precipitation patterns systematically increase the risk of conflict, often substantially" (p. 1), and, building upon similar assumptions, Raleigh, Choi, and Kniveton (2015) found evidence linking the relationship between climate variability and conflict to resource scarcity and its effect on local markets (p. 190). Therefore, despite the uncertainty surrounding the number of migrants that climate change has produced thus far, and may produce in the future (Wyman, 2013), climate change's influence on access to resources and resource distribution seems to be a significant determinant of climate change migration. 


\section{Migration as adaptation to climate change.}

Until recently, a securitization discourse surrounding climate change and migration has prevailed (Oels, 2013). Dominant discourses concerning climate change have often discussed migration in an apocalyptic tone (Bettini, 2013), with prognoses of mass migration movements particularly from developing states (Oels, 2013) - and have portrayed migration as being inherently problematic (Chaturvedi \& Doyle, 2010). There is some evidence that this problematization of climate change induced migration was deliberately designed by developing state governments and environmental non-governmental organizations to elicit an alarmed response from the international community in order to force stakeholders into taking action to counteract climate change (Oels, 2013). However, governments of developed states have since reacted by increasing their control of migration, and the United Nations High Commissioner for Refugees has been criticized for continuing to problematize climate change induced migration under a securitization framework (Nash, 2015).

At the same time, movement towards what has been termed the 'environmental migration management discourse' is slowly becoming noticeable within climate change literature (Nash, 2015). This discourse recognizes migration as being natural and sometimes positive, even within the context of climate change (Nash, 2015), as well as framing climate change as a problem that can be controlled or managed. Migration is viewed as presenting an increasing set of opportunities for migrants, and is regarded as an adaptation measure with transformative potential (IOM, 2014). In line with this discourse, Adger et al. (2003) differentiate between voluntary 'desirable' and forced 'displacement' migration with respect to climate change. Migration is identified as a potential adaptive response to climate change, with voluntary 'desirable' migration being conducive to improved livelihoods and economic prosperity for those 
who relocate (Adger et al., 2003). However, where voluntary 'desirable' migration is not possible, the likelihood and necessity of forced 'displacement' migration will increase, resulting in a possible erosion of living standards, for potentially both the migrant and the host receiving state (Adger et al., 2003). Important to the environmental migration management discourse is the preservation of multiple adaptation options, including migration (Nash, 2015).

Support for environmental migration management is still lacking however. Evidence demonstrating the benefits of migration for climate change adaptation, and the negative consequences of preventing it, has been largely ignored, and most states' - developed and developing - governments and policies continue to give weight to securitization discourses by upholding a negative view of the relationship between migration and climate change (Tacoli, 2009). Contrarily, migration is reported to be the most common autonomous strategy employed to adapt to climate change (Nash, 2015), making opposition towards migration as an adaptation strategy counterproductive, since autonomous strategies are argued to be those with the most positive, transformative potential (Tacoli, 2009). Such widespread negativity surrounding migration in the face of climate change presents a challenge to individuals' abilities to exercise agency in decision-making about migration by necessarily limiting their migration options.

\section{Climate change and migration from SIDS.}

While many states are already experiencing the effects of climate change directly, SIDS in particular are threatened by ever-rising sea levels and increasingly severe extreme weather events (UNFCCC, 2005). Most significantly, these changes are disturbing ecosystems; compromising health outcomes; decreasing air, water, and soil quality; damaging infrastructure; and will likely render several SIDS uninhabitable by the end of the century (UNFCCC, 2005; Migration Policy Institute, 2013). In addition to environmental changes, several demographic, 
economic, social, and cultural factors have, in the past, influenced internal and external migration for SIDS, and are expected to continue influencing migration in the future (Campbell \& Warrick, 2014). For instance, though the threat of coastal inundation, flooding, or erosion might render settlement areas marginal or uninhabitable, prompting migration, it is also possible for land to remain physically secure in terms of shelter, but for threats to livelihoods - such as decreased food supply or fewer employment opportunities - and deteriorating habitat conditions - such as changing disease vectors and frequency of exposure to extreme events - to render areas marginal or uninhabitable for different reasons (Campbell \& Warrick, 2014). In this sense, while migration is considered a highly probable outcome for many SIDS, the decision-making processes leading up to that migration, and the nature of the migration itself are apt to differ considerably depending on how islanders' means of support are affected (Migration Policy Institute, 2013).

Despite the challenges of climate change being well known and some SIDS developing action plans exploring the possibility of migration for themselves (Kelman, 2015), international support and interest have been limited (Barnett \& Campbell, 2010). Even in the case of potential migration destinations, little attention has been given to the implications of migration from SIDS at either the individual or national level, much less to establishing decision-making processes for determining if, when, and how this migration might occur (Betzold, 2015). In the very few cases where specific migration agreements with states outside of SIDS have been created - such as New Zealand's 'Pacific Access Category' for labour migration from Tuvalu, Kiribati, and Tonga - a connection between that migration and climate change is not explicitly acknowledged (Kelman, 2015). Similarly, while billions of dollars in funding from developed states and NGOs is directed towards addressing climate change related problems in SIDS, despite the expressed 
preferences of these states, only a minimal percentage of this has gone towards the implementation of practical adaptation projects in communities, with a much greater proportion being allocated towards climate change research (Barnett \& Campbell, 2010). The relationships between climate change and migration in and from SIDS has therefore been largely neglected, and migration options available to inhabitants of SIDS experiencing climate change have remained limited (Kelman, 2015).

\section{The Politics of Climate Change Discourses}

Increasingly widespread acknowledgement of anthropogenic climate change has, for decades, spurred debates over how climate change should be addressed, with the discussion revolving predominantly around notions of mitigation and adaptation (Lesnikowski, Ford, Berrang-Ford, Barrera \& Heymann, 2015). While mitigation tactics endeavour to reduce the overall threat of future climate change in a proactive manner, adaptation strategies focus on social and environmental adjustments to accommodate the impacts of climate change in a reactive manner. Research indicates that anthropogenic climate change necessitates both mitigation and adaptation efforts, since humans have already set into motion at least an assured degree of climate change effects — only some of which are presently being felt (Lesnikowski, Ford, Berrang-Ford, Barrera \& Heymann, 2015). As such, the question for most policymakers has shifted from whether or not the climate is changing, to how best populations might 'manage unavoidable changes' through adaptation, and 'avoid unmanageable changes' through mitigation (Bierbaum, Holdren, MacCracken, Moss \& Raven, 2007). From the perspective of many developed states, which are status quo oriented in terms of economic growth, reactive adaptation strategies are often preferable. 
Though climate change is a global phenomenon, its impacts are experienced locally, and therefore there is no one suitable response to climate change (Hulme, 2009). At the same time, all responses to climate change are inherently political in that they reflect the biases and positionality of those who undertake them (Hulme, 2009; Eriksen, Nightingale \& Easkin, 2015). While there are a number of human activities that contribute to climate change, scientists and governments have preferred to reify climate change as greenhouse gas emissions, and mitigation recommendations have predominantly involved reducing carbon emissions, with other options, such as reducing livestock production and deforestation, receiving considerably less attention (Oels, 2013). Similarly, though climate change adaptation policies that empower individuals to make autonomous decisions have been shown to have the most positive impacts (Eriksen, Nightingale \& Easkin, 2015), adaptation has generally been conceptualized as a linear policy directive aimed at reducing the risks associated with climate change (IPCC, 2014; Lesnikowski, Ford, Berrang-Ford, Barrera \& Heymann, 2015). Governments often seek to address climate change through the implementation of state-level programs and policies, or the adoption of technologies (Ribot, 2011), rather than by eliminating the sources of vulnerability to the effects of climate change (Ribot, 2011; Eriksen, Nightingale \& Easkin, 2015). Such efforts might, for example, include linking poverty reduction frameworks to climate change adaptation schemes or providing local access to climate change knowledge, in order to remove barriers to individuals' participation and engagement in climate change adaptation decisions (Eriksen, Nightingale \& Easkin, 2015).

Which mitigation or adaptation strategies are promoted to manage climate change are ultimately dependent upon how the problem of climate change is perceived and socially constructed (Eriksen, Nightingale \& Easkin, 2015). The dominant climate change discourses 
produced by more powerful stakeholders, such as governments, global policy makers, and corporations, therefore have significant influence on what aspects of climate change are deemed significant, how they are addressed, and who is affected in the process (Cannon \& Müller-Mahn, 2010; Eriksen, Nightingale \& Easkin, 2015). For example, the ubiquitous concepts of 'vulnerability reduction' and 'resilience building' popular among intergovernmental agencies and international nongovernmental organizations might seem rhetorically non-controversial, but how they occur in practice depends on the particular interpretations of vulnerability and resiliency at play (Cannon \& Müller-Mahn, 2010). Both of these discourses prioritize the production of different types of knowledge, and emphasize particular responses to climate change. Particularly for developing states such as SIDS, with already limited power in the grand scheme of climate change, uncritical adherence to entrenched constructions of vulnerability and resiliency have the potential to perpetuate these existing limitations and undermine agency.

\section{Climate Change Discourses and SIDS}

\section{Discourses of vulnerability.}

The concept of vulnerability is at the center of much of climate change research, and the identification of states and individuals as being disproportionately vulnerable based on differential exposure to projected climate changes, sensitivity to the impacts of these changes, and ability to respond to these impacts has become a staple of climate change policy (Morss, Wilhelmi, Meehl \& Dilling, 2011; Dilling, Daly, Travis, Wilhelmi \& Klein, 2015). Vulnerability discourses commonly depict SIDS as at-risk or in danger (Füssel, 2007), with their physical survival increasingly threatened by climate change (Wilhelmi \& Klein, 2015).

Though vulnerability discourses of SIDS are generally intended to highlight the injustice of SIDS' experiences of climate change, with SIDS often adopting these discourses themselves 
in hopes of eliciting aid (Cannon \& Müller-Mahn, 2010), the consequences of framing SIDS as vulnerable are mixed. On the one hand, vulnerability discourses have drawn attention to the fact that SIDS are effectively blameless for anthropogenic climate change (Ribot, 2011), whereas developed states have been responsible for roughly eighty percent of cumulative fossil carbon emissions and sixty percent of cumulative greenhouse gas emissions since 1750 (Höhne \& Blok, 2005). These types of realizations have contributed to widespread acceptance of concepts such as that of the 'common but differentiated responsibilities' of states toward climate change, in which the differences in states' historical contributions and respective capabilities toward climate change are believed to necessitate a disproportionate division of these obligations between the two groups (Vanderheiden, 2014; Paris Agreement, 2015). And notions of SIDS as suffering the effects of climate change through no fault of their own are considered essential to financial aid mechanisms (Dreher \& Voyer, 2014).

Conversely, media's and intergovernmental organizations' uses of these discourses tend to rely upon classic tropes of island vulnerability, where the people on islands are imagined to face numerous restrictions due to their smallness, isolation, and fragmentation (Barnett \& Campbell, 2010). These depictions are often heavily focused on the developing status of SIDS, painting them as wholly dependent on external trade, tourism, and aid from developed states for survival (Barnett \& Campbell, 2010). Portrayals of SIDS as passive aid recipients are largely counterproductive to SIDS' plight against climate change since they allow developed states to justify the status quo by throwing money at the problem of climate change, without necessarily acknowledging their role in creating climate change (Dreher \& Voyer, 2014). In this sense, the focus on internal characteristics of SIDS as contributing to vulnerability diverts attention away from external drivers of climate change. Similarly, simplistic conceptualizations of the 
vulnerability of SIDS as arising solely as a result of climate change ignore the fact that there are other challenges facing these states, such as economic development, which climate change only exacerbates. This thinking gives rise to linear policy directives insinuating that eliminating climate change will eliminate SIDS’ vulnerability in general (Dreher \& Voyer, 2014).

Vulnerability discourses are most often belittling and perpetuate a weak, limiting narrative of SIDS. In terms of their capabilities with regard to climate change, SIDS are commonly framed as being helpless 'victims' of climate change without any of their own agency (Dreher \& Voyer, 2014). This image in combination with apocalyptic sinking island narratives of SIDS popularized by the media contributes to an understanding of migration as a singular unavoidable destiny for SIDS (Bettini, 2013). Predictions of future mass waves of migration from SIDS have led to the rise of the term 'climate refugee' (Bettini, 2013). This expression originated within the climate change science community when, in an effort to illustrate the seriousness of climate change, researchers began likening projected future migration patterns linked to climate change to those of contemporary political refugees (Campbell \& Warrick, 2014). The term has since been heavily embraced by the media, and also receives backing from human rights organizations arguing that climate change migrants are in a similar situation to that of political refugees (Gemenne, 2015).

Most scholars and governments agree that it is inappropriate to speak of climate change migrants as refugees since there is no legal basis for the use of the term (McAdam, 2011; Mayer, 2015; Khan, 2014). The 1951 Geneva Convention definition requires that a refugee claimant be outside of their country of origin, and unable or unwilling to "avail themselves of the protection of that country owing to a well-founded fear of being persecuted" (Refugee Convention, 1951, p. 14). Refugee standing is rejected on the basis that many climate change migrants will never 
cross a border (Methmann \& Oels, 2015), and climate change-induced migration is not the result of the implied 'political' persecution (Fernández, 2015). Much of the recent debate surrounding climate change migrants being viewed as refugees revolves around how the Geneva Convention definition of a refugee might be expanded to recognize climate change as a form of political persecution carried out by developed states against developing states (Gemenne, 2015; Nishimura, 2015). Though many SIDS recognize the injustice of their situations, they also vehemently object to the label of 'refugees' since their governments are not persecuting them, and most do not wish to be perceived as being 'forced' to leave their homes (Dreher \& Voyer, 2014).

Despite increasing evidence that migration from SIDS might take on a different shape than the waves of indistinct crowds predicted by the media (Connor, 2016), and especially so in absence of a protection framework to accommodate them, this imagery has had a lasting effect on conceptions of migration from SIDS. Since sea-level rise is often concentrated on exclusively as the only form of climate change threatening SIDS - to the point that adaptation efforts aimed at other effects of climate change are marginalized (Campbell \& Warrick, 2014) - migration has come to be seen as a last resort for SIDS (Tacoli, 2009). This has contributed to a narrow standardization of migration from SIDS as a response to climate change that will only occur when all adaptation efforts have been exhausted, with migration being seen as a failure to adapt rather than a possible adaptation strategy (Tacoli, 2009). With very few exceptions, appeals for climate change refugee status in developed countries from citizens of SIDS have been rejected for their lack of precedent $(\mathrm{Ni}, 2015)$. 


\section{Discourses of resiliency.}

The notion of resiliency - previously confined to ecology disciplines - has, in recent decades, gained considerable traction in human security discourses (O'Brien, Eriksen, Nygaard \& Schjolden, 2007), and is a main theme of climate change policy (Methmann \& Oels, 2015; Paris Agreement, 2015). Common interpretations of resiliency emphasize an ecological or social system's capacity for endurance, self-organization, and adaptation in the face of change (Folke, 2006; Dryzek, Norgaard \& Schlosberg, 2011). When applied in a climate policy sense, resiliency typically denotes a broad approach to managing humans' experiences of climate change. Overwhelmingly, resiliency is presented as an empowering reconceptualization of basic climate adaptation, accounting for the differentiated relationships to climate change existent worldwide, and allowing for appropriate, respective responses (Methmann \& Oels, 2015; De Souza, Henly-Shepard, McNamara \& Fernando, 2015).

In response to many of the stereotypes emerging from vulnerability discourses, a growing body of ground level, community-based research has endeavored to change the narrative surrounding SIDS and climate change, and restore agency to SIDS, by highlighting their resiliency. As opposed to the stories of victimhood prevalent in the media, SIDS are not helpless against the effects of climate change, nor are they waiting for developed states to save them from climate change (Betzold, 2015). They already adapt autonomously to climate change on a regular basis and in a variety of ways (Connor, 2016), and many SIDS have extensive local knowledge of climate change (Barnett \& Campbell, 2010). In contrast to many developed states that have yet to experience significant loss and damage from climate change, SIDS have already been directly exposed to climate change and are better capable of taking measures to minimize 
further damage, and thus less sensitive to its future effects (Barnett \& Campbell, 2010). SIDS are active and resourceful actors in the face of climate change.

Resiliency discourses as they appear in intergovernmental policies and reports routinely produce a different picture of SIDS, however. Island life is viewed to be lacking complexity and tied to the land in a backward sense (Betzold, 2015). These framings reflect a romanticization of island life in which vague allusions to island knowledge as a tool for climate change adaptation and references to islanders' deep attachments to nature are rampant (Barnett \& Campbell, 2010). While islanders do benefit from traditional knowledge, it is "individually owned rather than publicly disseminated" (Connor, 2016, p. 30), and contrary to understandings of migration as being in opposition to culture, population mobility is an inherent part of island culture (Barnett \& Campbell, 2010). In this sense, resiliency is, for its wide-ranging applicability, a nebulous and highly politicized concept (Eriksen, Nightingale \& Easkin, 2015).

In the international arena, the language of resilience provides a common goal for policymakers from various backgrounds to work toward, and creates a forum for dialogue that might otherwise not have been possible. In the face of increasing climate variability, resilience has become a scientifically and socially legitimated objective, and states are urged to craft their own climate resilience strategies (Termeer et al., 2011). However, the vagueness surrounding what standards resilience actually demands has led many to question its practical relevance to climate policy (Bahadur, \& Tanner, 2014). This has led to the suggestion that resilience has become little more than a "boundary object" — an inherently ambivalent term that creates the illusion of common ground where there is none (Brand \& Jax, 2007, n.p.). Because its precise meaning remains subjective and open to interpretation, all stakeholders feel justified in pursuing their own competing aims and interests in accordance with resilience. This reframing of climate 
change adaptation has resulted in the individualization of states' responses to climate change (Baldwin, 2013), and such unpredictability and diversity of responses can limit international legal and institutional reform, ultimately eliminating the political space for addressing the root causes of climate change and vulnerability to climate change.

Representations of SIDS as climate 'heroes' are arguably just as harmful to SIDS' agency as the 'victimizing' narratives of vulnerability discourses. At the same time as SIDS are resilient, the rate and scale of climate change and future climate events are such that migration is, and will continue to be, a reality. Depictions of islanders as not viewing abandonment as an option not only neglect the fact that populations from several SIDS are already migrating, but also keep the discourse surrounding climate change migration firmly rooted in the "futureconditional tense", absolving developed states of any responsibility towards the climate change migrants who do emerge (Baldwin, 2016, p. 84). Exaggerating the independence of SIDS results in them facing climate change both figuratively and literally alone.

Since SIDS collectively contribute very little to climate change, their best efforts against climate change are counteracted when significant action from those states that are most responsible for the problem is not forthcoming. And, in this sense, how developed states choose to address climate change and its impacts matters immensely to SIDS. The climate change discourses of vulnerability and resiliency are often used to uphold a narrow interpretation of suffering and agency as being incompatible, perpetuate reductive stereotypes of SIDS, relegating other experiences to the periphery, and continue the myth of migration as a last resort option. In this research paper, a case study of the SIDS Kiribati is used to demonstrate how discourses of vulnerability and resiliency can also work to limit the migration opportunities available to SIDS. A methodology detailing the approach taken in conducting this case study is presented below. 


\section{METHODOLOGY}

The intention of this research paper is to examine the discourses of vulnerability and resiliency as they are commonly applied to SIDS experiencing climate change, and explore the impacts that such discourses have on migration from SIDS due to climate change. To accomplish this, a review, as seen above, of the relevant literature on climate change, migration, discourses of vulnerability and resiliency, and SIDS has been conducted. In the next section, the SIDS of Kiribati is used as a case study to ground this research. Following an overview of Kiribati and its relationship with climate change and migration, a discourse analysis of various stakeholders' conceptions of the vulnerability and resiliency of Kiribati is carried out. Of particular interest to the analysis are how these discourses frame and shape discussions and debates about Kiribati, climate change, and migration, and how the people of Kiribati's (IKiribati) agency is affected in the process. In order to apply this to my research, I use a climate justice framework to examine the current discourses that are being produced about I-Kiribati, climate change, and migration, paying specific attention to the power relations between stakeholders and the perspectives of marginalized I-Kiribati voices.

The choice of Kiribati as the focus of the case study has been informed by purposive sampling (Creswell, 2013). At the same time as Kiribati's case is typical, in the sense that there are several SIDS currently experiencing climate change induced migration, Kiribati is also notable for its climate change adaptation plan, the 'migration with dignity' policy, which is representative of I-Kiribati's desire to maintain dignity whilst managing these phenomena. This policy - which will be considered more completely in the case study - has garnered the island nation more attention than in previous years, and has elicited a variety of reactions among I-

Kiribati, neighbouring states, intergovernmental agencies, media, and scholars. Importantly, the 
'migration with dignity' policy has been instrumental in more recent framings of Kiribati as 'resilient' in the context of climate change.

The goal of analyzing the impacts of discourses of vulnerability and resiliency in the case of Kiribati is not to make generalizations about all SIDS experiencing climate change and migration based on the conditions of one. As is discussed in the literature review, significant differences in terms of geography, land size, population, local cultures, governance, infrastructure, development, and resources distinguish the case of each SIDS as unique from the others, which impacts the framing of discourses. Kiribati is treated in this case as an example. Among other points, its colonial past, development status, demographic challenges, and international relations illustrate some of the complexities associated with SIDS' responses to climate change and related migration. These factors and more inform I-Kiribati's migration decisions and underscore their agency, while also playing into discourses of vulnerability and resiliency.

In addition to permitting research to be focused on a particular case in order to be able to explore in the necessary depth (Darke, Shanks \& Broadbent, 1998), a case study approach allows for flexibility in the sources of data to be used (Stake, 1995). While case study research is generally much more systematic in terms of data collection and sampling standards (Creswell, 2013), due to the limited availability of data sources pertaining to Kiribati, and the impracticality of traveling to Kiribati or conducting interviews with I-Kiribati, the regular sampling boundaries of case study research were relaxed for the purpose of this study. A literature-based case study was conducted, guided by Stake's (1995) logic that case study is "non interventive", and if the necessary information can be gleaned through examination of records, it is sufficient (p. 12). Many different sources including existing scholarly works; government and policy 
documents; and books, media sources, and websites concerning Kiribati make up the sample from which data was drawn. Guided initially only by the goal of finding accessible sources related to Kiribati, climate change, and migration, the study was largely inductive (Creswell, 2013). The research direction was adjusted as different angles were presented in sources, and new data contributing to the content of the case was added until no longer deemed useful (Creswell, 2013).

This study of Kiribati is inherently limited by the fact that it is based only on secondary data accessible to and deemed relevant by myself, the researcher. As such, information not included or taken into consideration by the original authors is naturally excluded from my own depiction of Kiribati. Additionally, this case study has not benefited from the involvement of IKiribati, as interviews were not practical. Though human participation is not imperative to presenting a case study, the effects of climate change as they relate to Kiribati and the vulnerability and resiliency of I-Kiribati are discussed, and there is therefore the risk that IKiribati have been misrepresented either in terms of their experiences of climate change, or in terms of their attitudes or capacities towards climate change.

The lack of both local and global media publications from Kiribati available online in English has also heightened the risk of misrepresentation. These resources might have offered a valuable opportunity to contrast local media framings of I-Kiribati with global framings, adding another dimension to the analysis of the discourses of vulnerability and resiliency at play. In order to mitigate the risk of the misrepresenting I-Kiribati, I have attempted to be conscious of the lack of I-Kiribati perspective throughout the course of my study. At the same time, because all of the documents informing this study are freely available to the public, there is likely very minimal risk associated with their use in my specific study — though representing the data 
judiciously has been a priority throughout the research and synthesis processes.

The case study approach employed in this research incorporated a strategy of discourse analysis guided by concepts from climate justice theory. A key component of conducting research regarding SIDS, climate change, and migration is acknowledging the unjust roots of climate change, and - by extension - the unjust roots of any migration related to climate change. Climate justice theory views climate change as a by-product of the excessive lifestyles enjoyed in rich, and - traditionally - developed countries (Seabrook, 2016). SIDS are united by both their common development challenges and their susceptibilities to climate change. While their populations collectively contribute less than one percent of total greenhouse gas emissions, they bear the brunt of the impacts of climate change (Thompson, 2016, p. 156). In response, many of the biggest offending developed states still hesitate to enter into legally binding climate change agreements that would compromise their inflated standards of living, and offer few pathways for the people living in SIDS to improve their livelihoods or adapt to climate change through outmigration (Vanderheiden, 2014; Dees, 2015).

Based on historical contributions to and relative capabilities towards climate change, climate justice theory holds developed states accountable for and - by extension - obliges them to support SIDS experiencing climate change. The political origins of discourses of vulnerability and resiliency and the actors producing them thus make climate justice extremely relevant to a case study of Kiribati, since these framings shape how climate change and resulting migration is perceived and acted upon. Specifically, the popularization of the notion of Kiribati as a “disappearing nation" (Korouaba, 2015, p. 233) by media, scientists, government officials, and intergovernmental agencies has linked any predicted future migration from Kiribati more directly to anthropogenic climate change (Zellentin, 2015). 
Discourse analysis as a methodology is useful and consistent with a climate justice theoretical framework because it highlights "the way social power abuse, dominance, and inequality are enacted, reproduced and resisted by text and talk in the social political context" (Van Dijk, 2001, p. 352). The intention of this research is to interrogate the use of discourses of vulnerability and resiliency by answering the questions of: who is using these discourses and why?; how do these discourses impact I-Kiribati?; what are the underlying understandings of climate change and migration that are being produced or reinforced?; how do framings of vulnerability and resiliency coming from within and outside of Kiribati compare?; and, how does this influence the way in which I-Kiribati migration is conceptualized in general?

The ways in which I-Kiribati are perceived with respect to climate change by various stakeholders to suit different agendas, are extremely consequential to I-Kiribati since they necessarily impact their ability to exercise agency in making migration decisions. I-Kiribati outmigration spurred by climate change is, for instance, unlikely to be accommodated by receiving state actors rejecting the connections between climate change and migration or climate change and the migration of I-Kiribati specifically. Deconstructing whose agendas these discourses privilege draws attention to important issues of power, history, and politics underlying climate change responses (Tonkiss, 2004). 


\section{CASE STUDY: KIRIBATI}

\section{Backgrounder on Kiribati}

\section{Physical and human geography.}

Located on the equator halfway between Australia and Hawaii, Kiribati is a low-lying central Pacific SIDS comprised of one raised limestone island and thirty-two atolls (Roman, 2013). Atolls are islands made from dead coral and are considered by climate scientists to be highly vulnerable to sea level rise, as they often obtrude only a few meters above sea level (Weiss, 2015a). Though the country extends five thousand kilometers from east to west, and two thousand kilometers from north to south, spanning nearly 3.5 million square kilometers, its actual landmass covers less than eight hundred square kilometers, making it one of the world's smallest nations (Roman, 2013). Additionally, Kiribati is the only country in the world to have territory in all four hemispheres (Roman, 2013).

The atolls of Kiribati formed millions of years ago around the rims of sunken, undersea volcanoes (Weiss, 2015a). As sea levels rose, and the volcanoes sank deeper into the ocean, coral reefs grew, and eventually produced enough rubble and sand above the surface to form land (Weiss, 2015b). Resultantly, many of the islands of Kiribati are circular with shallow lagoons at their centers (Weiss, 2015a). Today, the coral atolls are concentrated into three distinct chains, in turn connected by narrow strands of sand (Weiss, 2015b): the Gilbert group of sixteen islands, the Line group of eight islands, and the Phoenix group of eight islands (Roman, 2013). Most of the land in Kiribati is less than two meters above sea level, and maximum elevations are roughly three meters (Donner \& Weber, 2014), with the exception of the limestone island Banaba, the nation's highest point, where the land reaches a maximum elevation of eighty-two meters above sea level (Weber, 2016). 
Of the thirty-three islands of Kiribati, only twenty-one are inhabited (Weber, 2016), with more than ninety percent of the population living on the Gilbert Islands (US Department of State, 2011). Kiribati has a population of roughly 114,000 people, and an annual population growth rate of $2.2 \%$ (Weber, 2016).

\section{History.}

The first settlements appeared on what are now known as the Gilbert Islands sometime between 3000 BC and 1300 AD (US Department of State, 2011). The original inhabitants of Kiribati are a Micronesian people, though invasions by Samoans, Fijians, and Tongans later introduced Melanesian and Polynesian populations (US Department of State, 2011). European contact began in the sixteenth century, and over the next two centuries, islanders were colonized and enslaved for primarily economic and military purposes (Roman, 2013). Many transformative changes including but not limited to the introduction of fatal diseases, new religions, and cash-based economies took hold over this time, resulting in conflicts among local tribes, lasting health consequences, permanent environmental damages, and countless deaths (Roman, 2013).

The discovery of rich phosphate rock deposits on Banaba Island in 1900 attracted considerable interest and subsequent exploitation, and, together with the Gilbert Islands, Banaba became part of a British colony in 1916 (US Department of State, 2011). Following this, the Line Islands and Phoenix Islands were incorporated into the colony over a twenty-year period (US Department of State, 2011). During World War II some islands were seized by Japan, and battles between Japanese and U.S. forces raged in the region (US Department of State, 2011). In the 1950s and 1960s, others were used as nuclear testing sites (Roman, 2013). The islands began pursuing self-governance in the 1970s, and eventually became a sovereign democratic republic, 
under the name of Kiribati, on July 12, 1979 (Roman, 2013). Post-independence, Kiribati has had four presidents (US Department of State, 2011). The most recent president, Taaneti Mamau, was elected in March 2016 (Economist, 2016), after Anote Tong, who had held the presidency since July 2003, stepped down (US Department of State, 2011).

\section{Contemporary development challenges.}

Kiribati has been identified by the United Nations as one of the least developed countries in the world based on economic, environmental, and social measures (Ni, 2015). Development indicators such as per capita gross domestic product (GDP), infant mortality, access to water, and sanitation are among the lowest in the Pacific (Weber, 2016). While 63.6\% of the Kiribati people - who are called I-Kiribati - are economically active (US Department of State, 2011), less than a quarter of the population participates in the formal wage economy ( $\mathrm{Ni}, 2015)$. Instead, most I-Kiribati survive through subsistence farming or fishing (Ni, 2015). Kiribati's per capita gross domestic product is $\$ 1500$ USD (US Department of State, 2011).

In Kiribati, forty-three out of every thousand babies die before their first birthdays, and these deaths are largely attributable to waterborne illnesses (Roman, 2013). Each year, one in five I-Kiribati receives medical attention for diarrhoea or dysentery, and in Kiribati's capital, Tarawa, where all natural water sources are either polluted, or at risk of pollution, four children die from diarrhoea every month (Roman, 2013). Though sewage systems were installed in the 1980s following a cholera outbreak, the infrastructure has not kept pace with population growth (Ni, 2015), and sewage is now leaking into the atolls' natural aquifers (Roman, 2013).

While there are high levels of infant mortality, the birth rate is also high, as Kiribati has one of the lowest contraceptive prevalence rates in the Pacific, and is the only country in the Pacific where contraceptive use is higher in rural areas than in urban areas (UNFPA Pacific, 
2014). Overcrowding in urban areas, a lack of toilets and sanitation resources, and informal settlements atop aquifers all contribute to groundwater contamination $(\mathrm{Ni}, 2015)$. Clean water supplies are overdrawn and some businesses only turn on their water for a few hours a day in order to deter the residents from tapping into their wells (Roman, 2013). Additionally, waste from islands pollutes the lagoons, poisoning reef fish and making them dangerous for consumption $(\mathrm{Ni}, 2015)$.

\section{Kiribati and Migration}

\section{Internal migration.}

Since 1969, Kiribati has experienced a roughly six-fold increase in population (Donner \& Weber, 2014). Following independence, high birth rates and ongoing urbanization spurred migration from outer islands to the capital Tarawa (Weiss, 2015a). Previous subsistence farmers and fishers arrived en masse seeking employment, cash, and education opportunities (Weiss, 2015a). Today, more than half of Kiribati's residents live on Tarawa, making it one of the most densely populated places in the Pacific (Weiss, 2015a). Settlements now extend far beyond the traditional beach ridges to unprotected flood-prone stretches of shoreline and reclaimed swampland (Donner \& Weber, 2014).

A program of directed migration out of Kiribati was developed in the mid-1990s in response to severe overcrowding exerting pressure on already limited freshwater resources and sanitation systems. Nearly five thousand I-Kiribati were relocated from Tarawa to outlying islands before the resettlement program lost support (US Department of State, 2011). Subsequent efforts to control population growth and curb migration to Tarawa have been mostly unsuccessful, and over the next fifteen years, Tarawa's population is projected to double (Weiss, 2015a). 


\section{External migration.}

Kiribati has long been characterized by the outmigration of contract labourers to work in the international shipping and mining industries - mostly on neighbouring islands (Roman, 2013). Currently, 750 I-Kiribati are employed as seafarers with German shipping lines, and 625 are employed as fishermen with Japanese, Korean, Chinese, and Taiwanese fleets (Government of Kiribati, 2015). However, over the past few decades, the combination of a rapidly increasing population, deteriorating environmental conditions, and a declining economy has persuaded many more I-Kiribati to search for opportunities abroad. In 2011, 4,337 I-Kiribati citizens, representing 4.2 percent of the national population, left Kiribati (Kiribati National Statistics Office, 2015). In recent years, twenty-one percent of migrating I-Kiribati have end up in Fiji and twenty-nine percent in New Zealand (UNU-EHS, 2015), with Australia, Japan, and Germany as the next most popular destinations in order of importance (Kiribati National Statistics Office, 2015). Employment opportunities, climate stressors, and education are currently the most significant motivations for international migration at forty-one percent, twenty-three percent, and nineteen percent respectively (UNU-EHS, 2015).

A few countries offer permanent migration schemes directed specifically at SIDS in the Pacific as a means of providing humanitarian assistance. Under its Pacific Access Category (PAC), every year since 2002, New Zealand has reserved seventy-five spots for I-Kiribati who would otherwise not meet the requirements for permanent residency. Individuals between the ages of eighteen and forty-five are selected through a lottery process and invited to apply provided that they meet minimum English language, health, and character requirements. Lottery winners must secure employment within six months in order to stay in New Zealand. The scheme is self-funded by applicants, and some I-Kiribati draw from their pensions to cover all of 
their expenses (Government of Kiribati, 2015). Until 2014, Australia offered the Kiribati Australian Nursing Initiative (KANI) program as an opportunity for I-Kiribati to gain internationally recognized nursing credentials. By the end of the program, seventy-eight students had graduated from the program in total, and forty-six were employed outside of Kiribati (Government of Kiribati, 2015).

I-Kiribati also pursue employment overseas through programs such as New Zealand's Recognized Seasonal Employer scheme and Australia's Seasonal Work Programme (SWP); however, they face high competition from other Pacific island countries. In 2014 only 168 IKiribati were successful in achieving work through the Recognized Seasonal Employer scheme and Australia's Seasonal Work Programme (Government of Kiribati, 2015). Similarly, Australia offers multi-year work visas for work in lower-skilled jobs, and scholarships for technical and vocational training in Australian institutions to Pacific Islanders, though I-Kiribati are not guaranteed selection. I-Kiribati must compete with citizens of Nauru and Tuvalu for roughly fifty visas each year - the result of which has been that only 232 citizens of Kiribati have been awarded scholarships since the program's debut (Government of Kiribati, 2015).

Compared to other SIDS' populations in the Pacific, I-Kiribati have been identified by the United Nations University Institute for Environment and Human Security (2015) as having very limited opportunities for outmigration. In a recent study of Pacific SIDS' migration trends, nine percent of I-Kiribati surveyed stated that they would like to relocate but are currently unable to (UNU-EHS, 2015), signaling that existing migration pathways do not satisfy migration demands. 


\section{Kiribati and Climate Change}

\section{Climate change effects.}

Over recent years, Kiribati has experienced significant environmental changes affecting resources, animals, and people. Although sea level rise presents an existential threat (Ni, 2015), the more immediate problem has been increasingly unpredictable weather patterns (Government of Kiribati, 2014). In the past, Kiribati experienced two consistently occurring seasons:

'Aumaiaki', the dry season from April to September, and 'Aumeang', the wet season from October to May (Government of Kiribati, 2014). Now, irregular rainfall, and long periods of drought contribute to crop failures and reduced fresh water supplies across the country (Roman, 2013). The success of water-sensitive crops such as copra, the main cash crop for fifty-five percent of the population, has fallen, while other varieties of vegetation have declined due to loss of land suitable for agriculture, reductions in groundwater, saltwater intrusion in soils and groundwater, and storm surge-driven flooding (Government of Kiribati, 2014).

The majority of I-Kiribati rely on water catchment tanks and man-made wells for survival (Roman, 2013), and during the heavy rains following extreme drought-like conditions, these become ideal habitats for mosquitoes, which have been linked to vector borne diseases such as dengue fever (Roman, 2013). While there had been previous dengue outbreaks in Kiribati during the 1970s and 1980s, in 2010 alone, the Kiribati Ministry of Health reported more cases of dengue fever than it had seen cumulatively over the past ten years (Roman, 2013). Naturally occurring freshwater sources have also been affected by climate change. The porous limestone of the coral atolls used to act as a natural filtration system for the freshwater lens located below each atoll's surface (Roman, 2013). As storm surge has increased and sea levels have risen, the capacity of the limestone filtration system has become diminished (Roman, 2013). Waste runoff 
and sea water have rendered some wells completely unusable, seriously reducing already scant safe drinking water supplies (Roman, 2013).

Figures for sea level rise are imprecise, vary regionally, and are only indicative of average levels (Donner \& Weber, 2014); however, one commonly referenced estimate of the total average sea-level rise affecting Kiribati over the twentieth century is between twelve and seventeen centimeters (Aung, Singh \& Prasad, 2009), with the rate of sea-level rise in Kiribati exceeding the global trend overall (Donner \& Weber, 2014). Additionally, while warmer sea temperatures and increased levels of carbon dioxide have facilitated harmful lagoon algae growth as well as coral reef bleaching, significantly affecting Kiribati’s aquatic plant and animal life (Government of Kiribati, 2014), stronger and more frequent tidal surges have inundated settlements, destroyed vegetation and infrastructure, and contributed to major coastal erosion (Government of Kiribati, 2014).

\section{Kiribati and Discourses of Vulnerability and Resiliency}

\section{Kiribati as vulnerable.}

\section{External actors' uses of vulnerability discourses.}

Since the 1992 signing of the United Nations Framework Convention on Climate Change (UNFCCC), which acknowledged the threat of sea level rise to livelihoods and sovereignty in SIDS, and assumed limitations to SIDS' capacities to adapt on their own, international climate change policy has, in theory, aimed to support SIDS in managing the impacts of climate change (Donner \& Weber, 2014). However, developed states have not always lived up to this commitment. In 2002, Kiribati, along with a group of several other Pacific SIDS, considered filing a lawsuit against the United States and Australia for their refusal to sign the 1997 Kyoto Protocol — a global warming treaty limiting signatories' greenhouse gas emissions (Tait, 2002). 
In response, government representatives from both the United States and Australia asserted that the Kyoto Protocol would do little to help nations such as Kiribati that were already threatened by sea level rise (Tait, 2002), essentially invoking the narrative that SIDS' eventual eradication by climate change was a foregone conclusion to justify the continuation of their excessive, carbon-fueled lifestyles.

Kiribati's vulnerability to changing environmental conditions has been similarly appropriated throughout history to serve the agendas of more powerful actors. Upon discovery of phosphate in Banaba at the turn of the twentieth century, the British hastily negotiated a deal with the Banabans to mine their land at fifty pounds per annum for the next 999 years (Roman, 2013). Banaba was then colonized under the directive of intensive natural resource excavation (Roman, 2013), and authorities were soon pushing to have the Banabans relocated so that the phosphate could be mined more efficiently and extensively (McAdams, 2013). When Banaban elders resisted relocation, the colonial government manipulated them into leaving their homes by convincing them that environmental conditions posed a serious threat to humans living on the island (McAdams, 2013). The Banabans eventually even ended up using their own mining royalties to purchase a new settlement (McAdams, 2013).

In December 1942, the majority of the population was relocated to the previously uninhabited Rabi Island in Fiji, only to discover that they had been enormously misled (McAdams, 2013). They arrived during hurricane season, and many died from hunger and illness due to the unfamiliar environmental conditions (Roman, 2013). Meanwhile, the British continued to strip-mine Banaba until 1979, by which point the island was left defaced and exhausted of phosphate reserves (Weber, 2016). Over nearly eight decades, twenty-one million 
tons of phosphate had been removed, with the Banabans only ever receiving a fifteen percent share of the total profits (McAdams, 2013; Weber, 2016).

Around the same time, beginning in 1938, during a period of intense competition between the United States and Great Britain for territory in the Pacific, settlers from the southern Gilbert Islands were brought to the Phoenix Islands. Whereas in the past this scheme was thought to have been developed in response to overpopulation and hunger plaguing the region on account of changing environmental conditions, colonial archives have since revealed that resettlement occurred for no valid environmental reason, and that the population was instead used to push a political agenda (McAdams, 2013).

At this time, under the Guano Islands Act of 1856, American citizens were entitled to claim islands with guano deposits (excrement from birds that are used by humans as fertilizer) for the United States, provided that these islands were uninhabited (McAdams, 2013). Guano resources in the region had been grossly depleted during the nineteenth century, and the British were anxious to secure any remaining reserves for themselves (McAdams, 2013). In addition to its guano deposits, the development of air transport also made the Phoenix Islands a potentially strong investment for both commercial and defense reasons (McAdams, 2013). Therefore, for the British, creating permanent settlements on these islands became a priority.

As part of the scheme, each settler moved from the southern Gilbert Island, regardless of gender or age, received a plot of land on Phoenix Island with at least one hundred coconutbearing trees, provided that they gave up their land rights on their home islands (McAdams, 2013). Especially for islanders from densely populated atolls, the scheme claimed to offer an opportunity to improve their livelihoods. Upon resettlement, however, Gilbertese people experienced severe water challenges, frequent droughts, and agricultural difficulties (McAdams, 
2013). There is substantial evidence that the colonial government was fully aware of the climatic unsuitability of the Phoenix Islands, but opted to carry out the scheme anyway (McAdams, 2013), ignoring settlers' subsequent demands for evacuation through World War II, until a severe drought between 1949 and 1952 finally put the scheme over edge, and it was determined that the inhabitants could not be self-sustaining (US Department of State, 2011).

\section{Internal actors' uses of vulnerability discourses.}

While external actors, such as British state authorities, have often employed discourses of Kiribati's vulnerability as tools to pursue their own interests, with little regard for the long-term wellbeing of I-Kiribati, Kiribati has also come around to using its own vulnerability to climate change to its advantage in order to attract and encourage support from others. For instance, before stepping down in 2016, Kiribati's third president, Anote Tong, had been adamant in his efforts to bring climate change to the rest of the world's attention, and he drew heavily on the notion of Kiribati as a "disappearing nation" (Korouaba, 2015, p. 233) in order to do so. From early on in his presidency, he frequently described Kiribati as being unsalvageable and past the point of return, and estimated that his nation would become uninhabitable within thirty to sixty years $(\mathrm{Ni}, 2015)$. He was a vocal participant in international climate change negotiations, consistently calling for larger carbon emitting countries to discontinue unsustainable production and consumption habits that put pollution and profit above the lives of I-Kiribati. Bolstering his arguments with allusions to his people's desperation in the face of climate change, Tong suggested that the atolls of Kiribati were the early warning systems for the rest of the world $(\mathrm{Ni}$, 2015).

In view of Tong's and other government representatives' deliberate use of stereotypical framings of island vulnerability to mobilize climate action from other states, the disempowering 
representations of Kiribati's vulnerability to climate change dominating media and intergovernmental reports are - to a point - largely of Kiribati's own creation. However, Kiribati's image of vulnerability is also one of the few financial mechanisms that it has at its disposal, and therefore, if the vulnerability narrative employed by Kiribati in its pursuit of foreign aid is narrow and limiting, it is only in response to the narrow and limiting understandings of SIDS' vulnerability demanded and upheld by existing international financing structures.

By the time that Kiribati attained political independence, its only major economic resource - phosphate - had already been exhausted. Opportunities for industrial activity on the island were therefore extremely limited, and the economic growth needed to fund the GoK's development aspirations and improve I-Kiribati livelihoods was not forthcoming. In this context, Kiribati has, from the beginning, always needed to rely heavily on foreign aid. As a United Nations 'least developed country' (Ni, 2015), Kiribati already receives development assistance from more powerful developed countries, with foreign aid representing forty-seven percent of government revenue (US Department of State, 2011); however, emphasizing its status as a country also among those most vulnerable to climate change allows Kiribati to solicit additional aid from donors.

\section{The 'Kiribati Adaptation Plan'.}

In the late 1990s, based on its perceived vulnerability to climate change, Kiribati was selected by the World Bank as a viable site for a climate change demonstration pilot project (Donner \& Weber, 2014). Planning and research began soon after and the project was officially implemented in 2002 under the name of the Kiribati Adaptation Plan (KAP) with the support of the World Bank, the Global Environmental Facility (GEF), AusAID, and NZAID (Government 
of Kiribati, 2007). However, as the KAP was essentially the product of I-Kiribati bureaucrats marshaling their country's vulnerability to climate change to financiers' likings, the initial surrender of control necessitated by this interaction eventually carried over into the project itself.

The KAP is largely regarded as a failure by I-Kiribati and the GoK (Roman, 2013; Korouaba, 2015; Ni, 2015). Major criticisms of the project have highlighted its intensive focus on research and planning but few tangible developments to show for it, and minimal effort on the part of project coordinators to include local knowledge and points of view (Roman, 2013). The project has created distrust of externally funded adaptation programs and confusion over whose responsibility adaptation is among I-Kiribati (Korouaba, 2015). Phase I of the KAP was completed between 2003 and 2005 and focused on producing technical reports and developing strategies to integrate climate change risk assessments and adaptation into the government's planning. For each of the inhabited atolls, the most notable effects of climate change over the past twenty to forty years were identified (Government of Kiribati, 2007).

Phase II of the KAP began in 2006 with a $\$ 5.8$ million USD plan to design and implement cost-effective adaptation measures, and initially emphasized five core priorities: (i) policy development and awareness raising; (ii) coastal protection, including infrastructure and ecosystems; (iii) freshwater resource management; (iv) adaptation capacity building at the island and community levels; (v) and project management. However, due to a combination of personnel turnover, the inconsistent and short-term nature of aid flow, and a time lag between project decisions and approvals, insufficient progress was made (Roman, 2013). The scope of the KAP was greatly reduced in 2009 and freshwater resources, project planning, and protection in Tarawa, the capital of Kiribati, became the main focus of the project (Weber, 2013). 
Due to the uncertainty of sea level rise estimates, and the episodic nature of climate events, the GoK has typically preferred to prioritize 'no regrets' measures—flexible policies aimed at improving the living standards of I-Kiribati and reducing the risks associated with climate change, regardless of the severity of eventual climate change impacts (Donner \& Weber, 2014). 'Soft' adaptation strategies such as mangrove planting, which builds land through sediment accretion over time, ultimately reducing erosion and flooding, are emphasized over hard protection tactics such as physical barriers, which immediately protect coastal zones from climate change events (Donner \& Weber, 2014). However, following the restructuring of Phase II, constructing sea walls - a hard measure - with a locally replicable design, became the primary task (Donner \& Weber, 2014), indicating that producing physical evidence of the project's work was more important to the project coordinators than addressing I-Kiribati's long-term climate vulnerability.

Sea walls are controversial in Kiribati. Though there is a long history of constructing sea walls to protect from storm surge and high water events, rather than dissipating waves, research has shown that sea walls only redirect waves elsewhere, and consequently only exacerbate beach erosion over time (Donner \& Weber, 2014). Additionally, overcrowding in Tarawa has increasingly pushed settlements further outward toward the shoreline, leading I-Kiribati to engage in destructive beach-mining practices to acquire materials for the construction of informal sea walls (Donner \& Weber, 2014). Beach-mining has been shown to increase the likelihood of flooding by reducing the protective sand ridge that keeps high tides at bay (Weiss, 2015). These adverse effects are not well communicated, however, and sea walls continue to carry status among I-Kiribati and external climate adaptation financiers as effective solutions, 
and are the most popular adaptation measures in Kiribati, representing ninety-five percent of the engineered coastal structures in Tarawa (Donner \& Weber, 2014).

While the Phase II sea walls included a new vertical sandbag design, and represented a technical improvement upon common local sea walls built from coral rock and sand, they did not include any vegetation to dissipate wave energy, and thus did not meet engineering best practice standards (Donner \& Weber, 2014). Erosion occurred at the edges of some of the sea walls within months of construction, and when Phase II ended in 2011, approximately \$7.1 million USD of Global Environment Facility and donor funds had been disbursed on largely ineffective structures (Donner \& Weber, 2014).

Phase III of the KAP has been running since 2012 and aims primarily to improve longterm use and management of water resources through the development of rainwater and groundwater harvesting systems, clean existing water reserves, protect against coastal erosion by improving existing sea walls and investing in soft measures, and strengthen community capacity to manage the effects of climate change by developing locally governed adaptation programs (Government of Kiribati, 2014). The project has a budget of $\$ 10.8$ million USD and is set to conclude after 2016 (Donner \& Weber, 2014).

The KAP is demonstrative of the trade-offs that come with externally financed climate projects in SIDS. While SIDS stand to benefit immensely from these programs in terms of both the work that they do and the attention that they draw to their plight, the politics of climate change adaptation and financing require SIDS to submit to external conceptions of their vulnerability that are often based on reductive tropes and stereotypes about island life. In doing so, SIDS become subjects of external forces, institutions, and agendas that prioritize their own interests over the welfare of local populations. While Kiribati was able to free itself from the 
imposition of formal colonialism in 1979 when it gained independence, its recovery has since been significantly impeded by climate change. Kiribati's dependency on external funding to help it meet this challenge has forced the SIDS to maintain unequal relations with developed states in which local agency and priorities are always subordinate to those of financiers. As a country with exceedingly low carbon emissions, Kiribati bears little responsibility for climate change relative to developed states. However, owing to its colonial past, Kiribati has been put in the awkward position of having to turn to these same developed states for help and subjecting itself to the attitudes and values of others. In this forum the legacy of colonialism is carried on.

Researchers coming to Kiribati funded by developed states have often spent more time investigating the verity of climate change itself or claims of sea level rise than they have on implementing adaptation schemes (Roman, 2013). In these studies providing Kiribati with adaptation assistance is only a secondary goal, and the inappropriateness of resulting solutions such as poorly constructed sea walls - for protecting I-Kiribati from long-term climate change is insignificant next to the goal of finishing the project and producing demonstrable results. Yet, IKiribati are the ones who will have to live with the decisions of external stakeholders, long after their projects have ended and they have moved on. Because, in these situations, external actors come in the interest of exploiting I-Kiribati vulnerability to climate change as a means to an end - rather than reducing that vulnerability - they end up perpetuating existing limitations already affecting the region and undermining I-Kiribati agency in adapting to climate change.

\section{Misrepresenting I-Kiribati identities.}

Owing arguably to Tong's and local I-Kiribati government officials' rhetoric, Kiribati has received more attention from media, researchers, environmental nongovernmental organizations, intergovernmental agencies, and international governments over the past ten years than ever 
before. At the same time, this newfound attention has been wholly garnered based on an image of vulnerability to climate change that Tong and the GoK have actively projected on behalf of Kiribati and its people; and the resultant image of I-Kiribati as 'victims' of climate change (Weiss, 2015c) is not one that most I-Kiribati identify with. That the GoK brandishes Kiribati's vulnerability to climate change strategically does not mean that Kiribati is not in fact vulnerable to climate change. Kiribati is undoubtedly experiencing the effects of climate change. At the same time, the GoK's emphasis of Kiribati's vulnerability to climate change has had the effect of producing a misleading impression that all I-Kiribati live in constant fear of losing their islands to its effects.

In a 2014 interview, Tong suggested that denial of the seriousness of climate change was a luxury afforded only to those not living it, saying "If they believe that, let them come here" (Weiss, 2015c, n.p.). However, this opinion is contradicted by the many I-Kiribati who remain conflicted over the connection between their own experiences and climate change decades after the GoK first acknowledged its scientific legitimization and relevance to Kiribati (Roman, 2013). While general awareness of climate change itself is high among the populace and viewed as a national priority by the government, there is considerable confusion and disagreement over the actual implications of climate change for Kiribati (Ni, 2015). A few I-Kiribati question popular climate change discourse, believing that the consequences of climate change are being overplayed (Ni, 2015), and are of only marginal future concern (Roman, 2013). To these IKiribati, the GoK's intense focus on climate change directs resources and attention away from more immediate challenges such as overcrowding, unemployment, pollution, and health problems (Korouaba, 2015). Although President Tong was very popular among I-Kiribati overall - having been re-elected twice after his first term of service - some I-Kiribati have 
characterized him as more of a "climate change activist rather than a leader" (Korouaba, 2015, p. 237).

There are also I-Kiribati who doubt the existence of climate change entirely. Notably, there is a very strong discord between scientific evidence of climate change and religious doctrine within Kiribati (Donner \& Weber, 2014). Since the arrival of the first missionaries in the eighteenth century, Christianity has been one of the most transformative forces in society (Steiner, 2015). Currently, approximately ninety-one percent of the population is Christian (US Department of State, 2011), and the Church is a central institution of religious and social life to which I-Kiribati willingly devote their time, energy, and money (Steiner, 2015). This dedication has created some difficulties in raising climate change awareness among religious communities (Steiner, 2015). Many ministers with the power to influence congregations do not believe in climate change (Donner \& Weber, 2014). Alternatively, some I-Kiribati believe in climate change but also believe that God will save them from its worst effects (Steiner, 2015). This understanding stems from the biblical promise of God to Noah that he would not send another flood (Steiner, 2015). Tong addressed these beliefs in 2014 during an East-West Center presentation with an allegory:

An old woman stays behind during a flood, waiting for God to save her. Three times she turns down assistance from rescuers, and when she eventually drowns and goes to heaven, she asks why God never saved her. God replies, "I tried to save you three times, but you wouldn't come.” (Weiss, 2015c, n.p.)

To be sure, there are also a number of devout Christians who believe in climate change and are vocal about their experiences of climate change in both cultural and political arenas (Roman, 2013). Furthermore, there is evidence of former I-Kiribati climate skeptics beginning 
to change their positions on climate change as the effects of climate change persist and new information becomes available (Roman, 2013). However, while this newfound climate change acceptance is encouraged by the GoK for its potential to inspire climate activism, it also comes at a high emotional cost, causing great pain, anger, and fear for some I-Kiribati coming to terms with Kiribati's physical vulnerability to climate change (Steiner, 2015).

\section{Kiribati as resilient.}

\section{External actors' uses of resiliency discourses.}

In 2005, the GoK made a decision to focus exclusively on adaptation as its response to climate change (Donner \& Weber, 2014). At that time, per capita emissions in Kiribati were only seven percent of the global average, and less than two percent of per capita emissions in the United States (Government of Kiribati, 2007). Kiribati's already low fossil fuel use, contrasted with its high susceptibility to climate change effects, demanded an emphasis on adapting to, rather than mitigating, climate change. Invoking a climate justice discourse that their climate change troubles were not of their own making, Kiribati and other SIDS began what has become and ongoing effort to challenge developed states' perspectives on what constitutes equitable climate adaptation financing, arguing that current climate projects were not meeting their needs (Warne, 2015).

Most climate change financing is disbursed as part of traditional development assistance (Dervis \& Puritz Milsom, 2010), limiting the amount of support that SIDS can ultimately receive, and also what they are able to do with it. SIDS argue that climate change financing should be considered an entitlement rather than foreign aid because of developed countries' responsibility for the majority of historic greenhouse gas emissions and resulting climate change (Dervis \& Puritz Milsom, 2010). Separating climate change relief from development assistance 
would give SIDS more freedom in applying both types of support separately to projects of their choosing, instead of having to address development challenges and climate change simultaneously to the satisfaction of or under the direction of donors.

That most donor countries have rejected this proposal - arguing that development challenges and climate change are linked, making it difficult to separate the two (Dervis \& Puritz Milsom, 2010) - is unsurprising considering the failure of developed countries thus far to submit to binding emissions targets and to deliver on their climate change financing pledges. In 2009, developing states had received less than 3.8 percent of the $\$ 19.5$ billion USD that developed states had previously pledged to disburse towards climate change financing by that point (Dervis \& Puritz Milsom, 2010, p. 39). While development challenges and climate change do play into and exacerbate one another, lumping climate change together with development assistance has, in the past, allowed for surface treatment of both issues by developed states. Separating the two would necessitate a more thorough assessments of the challenge presented by climate change especially for SIDS - and undoubtedly result in more demands for aid from these states.

In response to complaints from countries receiving aid, some developed states have accused SIDS - including Kiribati - of deliberately using climate change to seek funds and support from the international community by linking as many of their nations' problems as possible to climate change $(\mathrm{Ni}, 2015)$. In the case of Kiribati specifically, making reference to studies citing evidence of atolls in Kiribati having either increased in area or remained stable over recent decades (Johnson, 2015), some developed states have argued that new reef growth will keep pace with any significant changes, and that sinking island narratives are being exaggerated (Roman, 2013). In other words, discourses of Kiribati's resiliency to climate change have been used against the country to deny its claim to enhanced climate change financing. 
Similarly, in response to the GoK's insistence that its population will eventually have to relocate due to climate change, surveys conducted by Australian government researchers demonstrating the unwillingness of I-Kiribati to relocate have been used to suggest that Kiribati's vulnerability to climate change is being overstated (Roman, 2013). This argument is hinged on the notion that there is only one type of response to climate change.

Resistance to the acknowledgement and remediation of the climate injustices in SIDS is part of a larger rhetoric of denial adopted by developed states in order to avoid having to confront their historical and ongoing systematic contributions to climate change. Thus far, states have avoided any kind of fault-based liability model of responsibility for populations experiencing climate change, and currently, in lieu of a legally binding framework for providing support to populations affected by climate change, states determine their respective obligations to populations experiencing climate change and the associated loss and damage at their own discretion (Eckersley, 2015). Judging from the fact that currently, in both Australia - the world's largest carbon emitter per capita - and the United States - the world's second largest carbon emitter overall - foreign aid accounts for less than one percent of the national budget, that discretion is not generous (Lowy Institute, 2015).

In recent years, developed and developing states alike have taken to emphasizing the resiliency of populations experiencing climate change, as opposed to their vulnerability. However, while SIDS' embracement of resiliency discourses represents an active effort on the part of islanders to counteract harmful, inaccurate misunderstandings, stereotypes, and tropes often deriving from discourses of vulnerability (Steiner, 2015), developed states' use of the term is much more tenuous. For example, Australia - which provides forty-five percent of Kiribati's total development assistance - claims to be committed to improving Kiribati's environmental 
resilience (Lowy Institute, 2015); however, without significantly reducing Australian emissions levels, and financing projects which take into considered I-Kiribati voices, it is unclear how Australia can support Kiribati’s resiliency.

The ambiguous policy implications of resiliency for Kiribati are further evidenced by the recent climate negotiations at the 2015 United Nations Climate Change Conference (COP-21) where 195 countries agreed to reduce emissions "as soon as possible" and to limit increases in global temperatures to "well below" 2 degrees Celsius (Paris Agreement, 2015, p. 4), all while actively working toward fostering "climate resilience" among vulnerable populations such as IKiribati (Paris Agreement, 2015, p. 25). How can developed states contributing the most to climate change - in terms of greenhouse gas emissions - claim to be actively supporting the resiliency of populations vulnerable to the effects of climate change, if they continue to set modest and non-binding emissions targets that neither compromise their high-carbon lifestyles nor have any discernible impact on the climate change being experienced now?

\section{Internal actors' uses of resiliency discourses.}

Media depictions of Kiribati's situation have, in many ways, misrepresented the experiences of I-Kiribati. Descriptions of the nation as being a "vanishing atoll” (Knight \& Leckie, 2015, n.p.) or "sinking state" (Purvis, 2016, n.p.) "forever locked in battle with the ocean" (Ives, 2016, n.p.) coming from the German, British, and American media, respectively, presuppose the fate of I-Kiribati and ignore the reality of their current situation. While their lives are currently affected by climate change, they are not yet threatened to the extent that media representations suggest. Additionally, Kiribati’s development challenges such as overcrowding and water issues are faced by other countries in the Pacific as well, and most I-Kiribati are still able to live contentedly while still being concerned about climate change. In view of this, as a 
response to disempowering vulnerability framings of their islands and people, some I-Kiribati have chosen to adopt a narrative of climate resiliency (Steiner, 2015). Rather than simply denying their islands' vulnerability to the effects of climate change, I-Kiribati use these discourses to articulate the complex relationships that they have with their environments and to explain why they feel compelled to take action (Steiner, 2015).

Moving away from representations of their victimhood and the inevitability of their fate, I-Kiribati engage in activities, such as music, drama, and dance, that spotlight their cultural and environmental heritage and their unwillingness to be victims of climate change sitting idle waiting for more powerful states to make a move. Through these activities, I-Kiribati reclaim their identities with respect to climate change by raising their voices, making their faces seen, and conveying their own lived experiences in contrast with external actors' narrow conceptions of their vulnerability. In many cases I-Kiribati have chosen to express their identities of resiliency through the arts (Steiner, 2015), as these provide a useful medium of expression allowing I-Kiribati to explain and account for the human dimension of climate change in which certain situations elicit emotional or irrational responses that scientific data cannot predict. Troupes of I-Kiribati travel around the world using their culture and art to raise awareness of their plight with climate change. For instance, as part of the 'Water is Rising' tour, three-dozen islanders from Kiribati, Tokelau, and Tuvalu - two neighbouring SIDS - came together to perform at international climate talks and universities across the United States (Steiner, 2015).

Most recently, David Katoatau, an I-Kiribati weightlifter, performed a dance at the 2016 Summer Olympic Games in Rio to highlight his country's experiences with rising sea levels and climate change, stating:

As a sportsman I have offered everything to my country but I cannot save it [...] 
The schools I have visited in Kiribati and the thousands of children I have met aspire to be something great. How do I lie to them and say their dreams are possible when our nation is disappearing? [...] The simple truth is that we do not have the resources to save ourselves. (Friedman, 2016, n.p.)

While Katoatau acknowledged Kiribati's vulnerability to the negative effects of climate change, his performance demonstrated his desire and determination to use his unique platform to raise awareness of his country's plight. The effectiveness of this appeal for support remains to be seen. Currently, the weightlifter is trending on social media and the American media has dubbed his performance the "saddest Olympic celebration" (Friedman, 2016, n.p.).

Through similar campaigns, I-Kiribati have drawn upon the concept of resiliency in order to build transnational climate advocacy networks. Employing the 'sea of islands' narrative embraced by many SIDS already, which highlights the interconnectedness of islands with places and people beyond themselves (Steiner, 2015), I-Kiribati emphasize the importance of combined efforts and multiple perspectives in meeting the challenge of climate change. This is an allusion to I-Kiribati's belief in the need for developed and developing states to work together to support each other through climate change.

\section{'Migration with dignity'.}

The GoK believes that the long-term habitability of Kiribati is threatened by climate change (McNamara, 2015). Low biodiversity, largely unarable land, and inadequate freshwater sources already make the low-lying atolls physically sensitive to climate change; and this sensitivity is only further exacerbated by demographic pressures. However, while international media and intergovernmental discussions of the risks faced by Kiribati have predominantly focused on the existential threat of sea level rise - with some projections suggesting that one 
hundred percent of the population will have to migrate by 2055 (Campbell \& Warrick, 2014) the GoK sees the slow onset processes associated with climate change as presenting a much more immediate threat (Farquhar, 2014). At the same time, though the islands are liable to become increasingly unsustainable, and eventually uninhabitable, long before they disappear, the GoK views the gradual nature of climate change and its effects as offering an opportunity for proactivity that does not typically exist in other instances of displacement (Farquhar, 2014).

While some I-Kiribati are adjusting to their changing environment by moving away from the shoreline, reinforcing poorly constructed sea walls, and reclaiming lands, in the absence of a sustainable long-term internal migration option, the GoK has taken measures to also enable some of its citizens to migrate abroad. The 'migration with dignity' policy is a labour migration plan first developed in 2006 as part of Kiribati's national climate change adaptation strategy (O'Brien, 2013; McNamara, 2015). The two interconnected priorities of this policy are (1) to create opportunities for I-Kiribati wanting to migrate abroad, and (2) to align the educational and vocational training opportunities available in Kiribati with those of potential receiving countries (McNamara, 2015).

Building on pre-existing cross-border labour arrangements, the scheme aims to provide IKiribati with advanced education and training to equip them with the skills necessary to qualify for permanent residency and integrate into a new country. The GoK's expectation is that IKiribati migrants will form expatriate communities in their countries of destination so that these communities may support future migrants, while also increasing the opportunity for remittances to be sent back. Remittances are already an important source of finance for I-Kiribati, amounting to fifteen percent of the GDP, and are essential for meeting basic needs and paying school fees, particularly on the outer atolls where income-generating opportunities are limited 
(UNU-EHS, 2015). Increased remittances might also result in increased development opportunities for I-Kiribati by increasing access to education, healthcare, and services, and improving livelihoods (UNU-EHS, 2015).

Facilitating increased outmigration that is self-directed and oriented to improving human capital for some I-Kiribati is also expected to reduce pressure on already limited resources (UNU-EHS, 2015). While migration from rural to urban regions of Kiribati has helped to relieve the pressure caused by climate change in rural areas, the resultant urban growth has exacerbated pre-existing development challenges and also created numerous new problems (Campbell \& Warrick, 2015). Land disputes, increasing unemployment, overdrawn resources, and the growth of informal settlements, which are increasingly located on sites most sensitive to climate change, have resulted in reduced livelihoods for all I-Kiribati in these regions (Campbell \& Warrick, 2015). The GoK asserts that outmigration therefore has the potential to improve livelihoods for I-Kiribati within and outside of Kiribati.

Finally, the increased social capital resulting from migrants' periodic or permanent return is also expected to benefit Kiribati through the transfer of innovative skills, knowledge, and technologies (Campbell \& Warrick, 2015). The potential of this was supported by a 2013 study of I-Kiribati diaspora populations in New Zealand, Australia, and the United States in which interviews of those who had left Kiribati revealed that they were much more likely to consider climate change to be a threat than I-Kiribati (Roman, 2013).

As an extension to the 'migration with dignity' scheme, in May 2014, the GoK purchased six thousand acres of land in Fiji for $\$ 8.77$ million USD. The land was owned by the Anglican Church as part of the Natoavatu Estate located on Fiji's second biggest island of Vanua Levu (Pala, 2014). While the land is presently being used to grow food for the Kiribati population, the 
GoK has suggested that it will also eventually be incorporated into Kiribati's long-term nationwide relocation strategy (Pala, 2014). Plans of relocating eighteen to twenty thousand IKiribati to Vanua Levu have been discussed (Pala, 2014), and, following the land purchase, thenPresident Anote Tong announced:

I'm glad we've taken this milestone with Fiji and hope that developed countries can engage with frontline countries like us in this arena, as a matter of taking simple actions rather than negotiating climate change issues where common ground is far from reach. (Government of Kiribati, 2014, n.p.)

If some I-Kiribati were to relocate to Fiji, they would not be alone, however. The Natoavatu Estate is currently occupied by descendants of labourers from the Solomon Islands who migrated to Fiji in the nineteenth century to work on coconut plantations (Pala, 2014). In 1947, the Anglican Church invited them to move onto the Natoavatu Estate indefinitely provided that they continue to practice the Anglican faith (Pala, 2014). After the GoK purchased the land from the Church, the 270 villagers were left with only three hundred acres, even though they had habitually required seven hundred acres to sustain themselves (Pala, 2014).

Migration is a key feature of Kiribati's history, and islanders have moved on account of shifting environmental, political, and social conditions for centuries. Despite this, Kiribati's 'migration with dignity' scheme has been met with scepticism and called radical by intergovernmental organizations and media characterizing the move as an unnecessary or extreme reaction by the GoK (Farbotko \& Lazrus, 2012). This characterization reveals a significant disconnect between the GoK's understanding of the hazards of climate change and those of external actors. The 'migration with dignity' scheme is perhaps the strongest indicator 
of the GoK's attitude towards climate change as it applies to Kiribati and the sincerity of its assertions that climate change threatens the long-term habitability of its islands.

While, in the past, colonial governments regularly pursued formal policies of resettlement in the face of environmental change - such as during a 1950s drought when hundreds of IKiribati were sent to settle parts of the Solomon Islands (McAdams, 2013) - their ability to do so rested on their status as a world power already holding ownership over the land picked for resettlement. Today, Kiribati does not have the same resources or clout at their disposal, and must enter into formal migration agreements with or purchase territory from other countries. Additionally, Kiribati is not interested in forcing its people to relocate against their wishes. Above all, 'migration with dignity' is representative of I-Kiribati's desire to maintain dignity and agency as climate change progresses.

Forecasts of Kiribati's eventual 'sinkage' have resulted in framings of I-Kiribati as 'climate change refugees' (Farbotko \& Lazrus, 2012) - a label which they vehemently reject. IKiribati do not wish to be seen as refugees because this categorization does not accurately reflect their situation (Steiner, 2015). Whereas political refugees are effectively victims of persecution that is carried out against them by their own government, in the case of the would-be climate change refugee, it is the actions of the governments of other hegemon developed states that are hindering their government's ability to protect its citizens (Gemenne, 2015). A main goal of 'migration with dignity' is to manage migration progressively through a coordinated approach in which I-Kiribati are able to exercise their agency in making migration decisions. In this sense, Kiribati's 'migration with dignity' scheme conforms to an environmental management discourse by attempting to preserve multiple adaptation options for its people. By facilitating as much voluntary 'desirable' migration as possible, the need for forced 'displacement' migration in the 
long-term will be lessened (Adger et al., 2003). The scheme is thus proactive rather than remedial and has the potential to result in positive outcomes in both Kiribati and receiving countries.

Media depictions suggesting that Kiribati is "planning for its own demise" and "urging" its residents to move away (Ives, 2016, n.p.) have, however, blown the scheme out of proportion and misrepresented how I-Kiribati want to respond to climate change in the long-term. While the GoK foresees a time when all I-Kiribati will have to relocate, it also acknowledges the desire of many to continue living on their land for as long as possible. For this reason, the scheme is structured with an aim to improve the livelihoods of all I-Kiribati regardless of whether they ultimately end up leaving Kiribati or not. The program will not force anyone who wishes to stay in Kiribati to leave against their will. At the same time, because the success of the scheme is largely dependent upon the cooperation and support of other countries, the scheme does not reach everyone - especially those with limited literacy skills - not all I-Kiribati will be given the option to leave, meaning that at least some of the population will inevitably be forced to stay in Kiribati against their will.

While Fiji's President has stated that his country will support Kiribati in whatever way that it can, larger developed states such as New Zealand and Australia have said that they will not participate in any official climate change migration scheme (Government of Kiribati, 2015), outside of existing labour migration and education pathways. This refusal of developed states to accept climate change migrants reveals a negative view of climate change migration and a clear preference for economic, skilled migrants. This is because, in a neoliberal context, climate change migrants are seen as a burden to receiving countries (Baldwin, 2013). In recent years, established pathways for migration from Kiribati have offered fewer opportunities to I-Kiribati 
due to competition from other states where levels of education and technical skills are higher. Even I-Kiribati with internationally recognized qualifications have experienced difficulties accessing overseas employment in developed states, and in the five years leading up to 2013, only eighteen I-Kiribati managed to migrate to Australia as skilled migrants (Government of Kiribati, 2015). In other words, while education can guarantee the employability of I-Kiribati, it does not necessarily guarantee their employment.

Though the GoK has been working to identify new migration opportunities for its people, the 'migration with dignity' scheme is lacking in the sense that while the main motivation underlying the scheme is climate change, the scheme itself is forced to rely on partnerships that do not formally acknowledge climate change and thus do not recognize the unjust social structures enabling "the systematic generation of harm" (Eckersley, 2015) leading to climate change induced migration. While the scheme allows I-Kiribati to maintain agency throughout migration decision processes, it does not hold the states responsible for that migration accountable, and thus does not create new pathways for climate change migration. Migrants' options therefore remain limited.

Finally, more than seventy percent of households in Kiribati feel that migration will be a likely future response to climate change if climate stressors increase (UNU-EHS, 2015); and though important political issues are bound to arise over an entire populations' resettlement and particularly in regards to the provision of land - it is ironic to think that I-Kiribati's efforts to maintain agency and self determination in making migration decisions might ultimately undercut the agency of another population since there are not clear pathways to employment. Additionally, in the case of the Fiji land plot, even though the villagers of the Natoavatu Estate did not pay for their land, they have been using it for decades and will now eventually be pushed 
off of it. The sale of this land was made without consideration of the impact that it would have on the population already settled on the land, suggesting that, as far as the Church in Fiji is concerned, they are a 'movable' people whose interests are subordinate - much in the same way that I-Kiribati have been treated by developed states throughout history, against the backdrop of environmental change. 


\section{CONCLUSION}

This research paper presented a case study of a SIDS in the Pacific called Kiribati currently confronted with the challenge of climate change. Kiribati's 'migration with dignity' program was discussed as illustrative of the complexities of climate change migration in the present day. The implications of two climate change discourses commonly applied to SIDS vulnerability and resiliency - for I-Kiribati were explored, and concepts from climate justice theoretical literature were used in this research as a framework for understanding vulnerability, resiliency, and responses to climate change. In order to provide context to the case study of Kiribati, a review of scholarly and policy literature discussing the relationship between climate change and migration was conducted. Focusing specifically on SIDS, the influence of discourses of vulnerability and resiliency on responses to climate change, with particular attention to migration within and from SIDS, was examined.

Discourses of vulnerability and resilience have been employed by actors both within and outside of Kiribati to serve varying agendas throughout history. When either discourse is coopted by developing states, it often results in the marginalization of I-Kiribati voices, and has, in some cases, contributed to their vulnerability to climate change. At the same time, I-Kiribati actors have also wielded discourses of vulnerability and resiliency strategically in order to help their country cope with the effects of climate change. While both discourses have had harmful impacts on I-Kiribati agency, they have also provided I-Kiribati with opportunities that they did not have before. As such, abandoning either discourse completely is unlikely to solve Kiribati's climate change problems. Instead, a compromise between the two is necessary.

The greatest challenge facing SIDS right now is the apathy of developed states towards climate change, and if the only way for SIDS to change that is by flaunting their vulnerability, 
then that might be a necessary trade-off. At the same time, developed states should provide financing for SIDS' responses to climate change without involving themselves in determining how those responses materialize. As the stakeholders with the most to lose, SIDS should retain autonomy in deciding for themselves how they respond to climate change. The best way to do this would be for developed states to grant SIDS' requests for climate change financing to be administered separately from traditional development assistance. Not only would this allow governments of SIDS more flexibility in applying donors' funds, it would also allow them to focus on climate change adaptation and development challenges separately. This is admittedly a suggestion that runs counter to the majority of opinions coming from the development and academic communities (Ayers \& Huq, 2008).

Given the close relationship between adaptation to climate change and development, use of traditional development assistance pathways to support developing states' through climate change is considered pragmatic (Ayers \& Huq, 2008). However, in the same way that not all adaptation strategies can be considered development, not all development policies reduce vulnerability to climate change — and especially so when the adaptation measures adopted by more powerful donors are incompatible with the development needs and priorities of recipient developing states (Ayers \& Huq, 2008). Additionally, climate change is the result of the unsustainable development practices used by developed states to get to where they are now, and in this sense, the responsibility of supporting developing states in coping with the effects of climate change is different from the responsibility to help them become more developed.

This is not to say that there is not a role for development organizations to play in helping developing states adapt to climate change; however, it is important to distinguish the role of development assistance from that of climate change funding. In Kiribati, for instance, though 
climate-proofing infrastructure and facilitating long-term migration options for I-Kiribati are important tasks, they should not supplant efforts to tackle the more immediate issues of malnutrition and water quality—both actions should be undertaken separately. Perhaps it is time to call into question developed states' conceptions of development and their motives for promoting it in developing states when it is preventing these same states from adapting to climate change.

While there is a clear need for governments of developed states to end their reliance on fossil fuels and keep carbon in the ground, this process will likely take some time. In 2015 at the United Nations Climate Change Conference (COP-21) 195 countries drafted an agreement to reduce their emissions, limit increases in global temperatures to under 2 degrees Celsius, and support populations experiencing climate change (Paris Agreement, 2015). In order for the agreement to go forward, at least fifty-five countries, accounting for at least fifty-five percent of total global greenhouse gas emissions, must have ratified the agreement (Paris Agreement, 2015). As of September 2016, twenty-seven countries have joined the treaty, and many of these are SIDS (UNTC, 2016, n.p.). Most recently, China and the United States - the world's two largest carbon emitters - formally added their instruments of approval of the agreement with the United Nations, bringing the total represented global greenhouse gas emissions up from what was previously 1.08 percent to just over thirty-nine percent (UNTC, 2016, n.p.). China's and the United States' participation in the Paris Agreement signals that developed states are beginning to consider climate change to be a priority.

For those states that have yet to approve the agreement, citizens and voters stand to play an important role. If governments are apathetic to climate change, it is largely because their citizens allow them to be. Citizens of developed states contribute to climate change by 
participating in and relying on the present market economy and the destructive conceptions of 'development' that it promotes. They also therefore have the ability to pressure their governments into acting sustainably and equitably by pointing out and challenging the unsustainable mode of the present economy. Every revolution has a point of rebellion where people know something is wrong but they are not yet sure what to do. SIDS know that something unsustainable is happening, and they are fighting it with the resources at their disposal, but it will not become a revolution until the necessary organization takes place. Citizens of developed states need to step up to the challenge.

More generally, it is necessary to establish a new narrative about the challenge of climate change in SIDS—one that effectively recognizes the climate change risks facing SIDS without victimizing them, accounts for the dependency of SIDS' responses to climate change on outside resources without denying their people's agency, and acknowledges the resiliency of SIDS without leaving them to face climate change alone. 


\section{REFERENCES}

Adamo, S. B. (2016). Migration, displacement and climate change: Understanding large Movements of refugees and migrants. (Powerpoint slides). Retrieved from http://www.un.org/en/development/desa/population/migration/events/other/other/docume nts/250416_COLUMBIA_UNI_Susana_Adamo.pdf

Alabi, S. (2016). Non-state actors and international climate justice under global climate governance. In C. Sampford, S. Zifcak, \& D. A. Okur (Eds.), Rethinking international law and justice (n.p.). New York, NY: Routledge.

Anderegg, W. R. L., Prall, J. W., Harold, J., \& Schneider, S. H. (2010). Expert credibility in climate change. Proceedings of the National Academy of Science, 107(27), 12107-12109.

Angus Reid. (2011). Britons Question Global Warming More Than Americans and Canadians. Retrieved from http://angusreidglobal.com/wpcontent/uploads/2011/09/2011.09.12_Climate.pdf.

Arnall, A., Kothari, U., \& Kelman, I. (2014). Introduction to politics of climate change: discourses of policy and practice in developing countries. The Geographical Journal, 180(2), 98-101.

Arvai, J., Gregory, R., Bessette, D., \& Campbell-Arvai, V. (2012). Decision support for developing energy strategies. Issues in Science and Technology, 28, 43-52.

Atapattu, S. (2016). Human rights approaches to climate change: Challenges and opportunities. New York, NY: Routledge.

Auffhammer, M., \& Carson, R.T. (2008). Forecasting the path of China's CO2 emissions using province level information. Journal of Environmental Economics and Management, 47, $47-62$. 
Aung, T., Singh, A., \& Prasad, U. (2009). A study of sea-level changes in the Kiribati area for the last 16 years. Weather, 64(8), 203-206.

Averchenkova, A., Stern, N., \& Zenghelis, D. (2014). Taming the beasts of 'burden-sharing': an analysis of equitable mitigation actions and approaches to 2030 mitigation pledges.

Centre for Climate Change Economics and Policy Grantham Research Institute on Climate Change and the Environment. Retrieved from http://eprints.lse.ac.uk/64537/1/Averchenkova-Stern-and-Zenghelis-policy-paperDecember-2014.pdf.

Ayers, J. M., \& Huq, S. (2008). Supporting adaptation to climate change: What role for official development assistance? International Institute for Environment and Development. Retrieved from http://www.iied.org/supporting-adaptation-climate-change-what-role-forofficial-development-assistance.

Bahadur, A., \& Tanner, T. (2014). Transformational resilience thinking: putting people, power and politics at the heart of urban climate resilience. Environment and Urbanization, 26(1), 200-214.

Baldwin, A. (2013). Racialisation and the figure of the climate-change migrant. Environment and Planning, 45(6), 1474-1490.

Baldwin, A. (2016). Premediation and white affect: Climate change migration in critical perspective. Royal Geographical Society, 41(1), 78-80.

Barnett, J., \& Campbell, J. (2010). Climate change and small island states: power, knowledge, and the South Pacific. London, UK: Earthscan.

Bell, A. (2016). A very short history of climate change research. Road to Paris (pp. 7-10). 
International Council for Science. Retrieved from

http://www.icsu.org/publications/communications-and-outreach/twelve-things-wevelearned-on-the-road-to-paris/twelve-things-weve-learned-on-the-road-to-paris.

Bettini, G. (2013). Climate barbarians at the gate? A critique of apocalyptic narratives on climate Refugees. Geoforum, 45(1), 65-72.

Betzold, C. (2015). Adapting to climate change in small island developing states. Climatic Change, 133(3), 481-489.

Bierbaum, R. M., Holdren, J. P., MacCracken, M. C., Moss, R. H., \& Raven, P. H. (Eds.). (2007). Confronting Climate Change: Avoiding the Unmanageable and Managing the Unavoidable. Scientific Expert Group on Climate Change (SEG). Retrieved from http://www.globalproblems-globalsolutions-

files.org/unf_website/PDF/climate\%20_change_avoid_unmanagable_manage_unavoidab le.pdf.

Bodansky, D. (2001). The history of the global climate change regime. In U. Luterbacher \& D. F. Sprinz, (Eds.), International Relations and Global Climate Change (pp. 23-40). Cambridge, M.A.: MIT Press.

Botzen W. J. W., Gowdy, J. M., van den Bergh, J. C. (2008). CO2 emissions: shifting international responsibilities for climate debt. Climate Policy, 8, 569-576.

Boykoff, J., \& Boykoff, M. (2004, November 01). Journalistic Balance as Global Warming Bias: Creating Controversy Where Science Finds Consensus. FAIR. Accessible at http://fair.org/extra/journalistic-balance-as-global-warming-bias/.

Brand, F. S., \& Jax, K. (2007). Focusing the meaning(s) of resilience: resilience as a descriptive concept and a boundary object. Ecology and Society 12(1), n.p. 
Burke, M., Hsiang, S. M., \& Miguel, E. (2014). Climate and Conflict (No. w20598). National Bureau of Economic Research. Retrieved from https://gspp.berkeley.edu/assets/uploads/research/pdf/Climate_and_Conflict.pdf.

Campbell, J., \& Warrick, O. (2014). Climate change and migration issues in the Pacific. United Nations Economic and Social Commission for Asia and the Pacific. Retrieved from http://www.unescap.org/sites/default/files/Climate-Change-and-Migration-Issues-in-thePacific.pdf.

Cannon, T., \& Müller-Mahn, D. (2010). Vulnerability, resilience and development discourses in context of climate change. Natural Hazards, 55(3), 621-635.

Chaturvedi, S., \& Doyle, T. (2010). Geopolitics of Climate Change and Australia's Reengagement with Asia: Discourses of Fear and Cartographic Anxieties. Australian Journal of Political Science, 45(1), 95-115.

Cloutier, G., Joerin, F., Dubois, C., Labarthe, M., Legay, C., \& Viens, D. (2015). Planning adaptation based on local actors' knowledge and participation: A climate governance experiment. Climate Policy, 15(4), 458-474.

Connor, L. H. (2016). Climate Change and Anthropos: Planet, People and Places. London, UK: Routledge.

Cook, J., Nuccitelli, D., Green, S. A., Richardson, M., Winkler, B., Painting, R., Way, R., Jacobs, P., \& Skuce, A. (2013). Quantifying the consensus on anthropogenic global warming in the scientific literature. Environmental Research Letters, 8(2), 1-7.

Corry, O., \& Jørgensen, D. (2015). Beyond 'deniers' and 'believers': Towards a map of the politics of climate change. Global Environmental Change, 32, 165-174.

Creswell, J. (2013). Qualitative Inquiry and Research Design: Choosing Among Five 
Approaches. Thousand Oaks, CA: Sage.

Darke, P., Shanks, G., \& Broadbent, M. (1998). Successfully completing case study research: combining rigour, relevance and pragmatism. Information systems journal, 8(4), 273289.

The David Suzuki Foundation. (2014). Climate Change Deniers. Retrieved from http://davidsuzuki.org/issues/climate-change/science/climate-change-basics/climatechange-deniers/.

Dees, J. P. (2015). The Ethics of Climate Change: Considering Scale and Responsibility. Papers \& Publications: Interdisciplinary Journal of Undergraduate Research, 4(1), n.p.

Dervis, K., \& Puritz Milsom, S. (2010). Responding to a changing climate: challenges in financing climate resilient development assistance. The 2010 Brookings Blum Roundtable Policy Briefs: Making development aid more effective. Retrieved from https://www.brookings.edu/wpcontent/uploads/2016/07/09_development_aid_dervis.pdf.

De Souza, R. M., Henly-Shepard, S., McNamara, K., \& Fernando, N. (2015). Re-framing island nations as champions of resilience in the face of climate change and disaster risk. UNUEHS Working Paper Series, No. 17. Bonn: United Nations University Institute of Environment and Human Security.

Dilling, L., Daly, M. E., Travis, W. R., Wilhelmi, O. V., \& Klein, R. A. (2015). The dynamics of vulnerability: why adapting to climate variability will not always prepare us for climate change. WIREs Climate Change, 6(4), 413-425.

Donner, S. D., \& Webber, S. (2014). Obstacles to climate change adaptation decisions" a case 
study of sea-level rise and coastal protection measure in Kiribati. Sustainability Science 9(3), 331-345.

Doran, P. T., \& Zimmerman, M. K. (2009). Examining the Scientific Consensus on Climate Change. Eos, Transactions, American Geophysical Union, 90(3), 22-23.

Draft Paris Agreement (Paris Agreement). (2015, December 5). Framework Convention on Climate Change. Hoc Working Group on the Durban Platform for Enhanced Action.

Dreher, T., \& Voyer, M. (2015). Climate Refugees or Migrants? Contesting Media Frames on Climate Justice in the Pacific. Environmental Communication, 9(1), 58-76.

Dryzek, J. S., Norgaard, R. B., \& Schlosberg, D. (2011). The Oxford handbook of climate change and society. New York, NY: Oxford University Press.

Dunlap, R. E., \& McCright, A. M. (2011). The politicization of climate change and polarization in the American public's views of global warming, 2001-2010. The Sociological Quarterly, 52(2), 155-194.

Edenhofer, O., Pichs-Madruga, R., Sokona, Y., Farahani, E., Kadner, S., \& Seyboth, K. (2014). IPCC, 2014: Climate Change 2014 - Mitigation of Climate Change. Contribution of Working Group III to the Fifth Assessment Report of the Intergovernmental Panel on Climate Change. Transport.

Eman, M. (2015, July 30). Debate: Peace and security challenges facing small island developing states. Kingdom of the Netherlands United Nations Security Council. Retrieved from http://www.nlinunsc.nl/what-we-say/kingdom-nl-statements-at-the-un/2015/08/debatepeace-and-security-challenges-facing-small-island-developing-states.

Eriksen, S. H., Nightingale, A. J., \& Easkin, H. (2015). Reframing adaptation: The political nature of climate change adaptation. Global Environmental Change, 35(1), 523-533. 
Farbotko, C., \& Lazrus, H. (2012). The first climate refugees? Contesting global narratives of climate change in Tuvalu. Global Environmental Change, 22(2), 382-390.

Farmer, G. T., \& Cook, J. (2013). Climate Change Science: A Modern Synthesis. New York, N.Y.: Springer.

Farquhar, H. (2014). "Migration with Dignity": Towards a New Zealand Response to Climate Change Displacement in the Pacific. Victoria University of Wellington Legal Research Paper, Student/Alumni Paper, (19).

Fatorić, S. (2014). Migration as a climate adaptation strategy in developed nations [Briefer No. 24]. The Center for Climate and Security. Retrieved from https://climateandsecurity.files.wordpress.com/2012/04/migration-as-a-climateadaptation-strategy-in-developed-nations_briefer-24.pdf.

Folke, C. (2006). Resilience: The emergence of a perspective for social-ecological systems analyses. Global environmental change, 16(3), 253-267.

Friedman, U. (2016, August 17). The Saddest Olympic Celebration. The Atlantic. Retrieved from http://www.theatlantic.com/international/archive/2016/08/david-katoatau-olympicskiribati/496175/.

Friman, M., \& Hjerpe, M. (2015). Agreement, significance, and understandings of historical responsibility in climate change negotiations. Climate Policy, 15(3), 302-320.

Füssel, H. M. (2007). Vulnerability: a generally applicable conceptual framework for climate change research. Global environmental change, 17(2), 155-167.

Geddes, A., Adger, W. A., Arnell, N. W., Black, R., \& Thomas, D. S. G. (2012). Migration, environmental change, and the 'challenges of governance'. Environment and Planning C: Government and Policy, 30(6), 951-967. 
Government of Kiribati. (2007). Climate change. Retrieved from http://www.climate.gov.ki/. Government of Kiribati. (2014). Kiribati Adaptation Plan. Retrieved from http://www.climate.gov.ki/category/action/adaptation/kiribati-adaptation-program/. Government of Kiribati. (2015). Kiribati National Labour Migration Policy. International Labour Organization. Retrieved from http://www.ilo.org/wcmsp5/groups/public/---asia/--ro-bangkok/---ilo-suva/documents/publication/wcms_431833.pdf.

Hasan, Z. (2015). Artisan Fishers' Perceptions of, and Adaptation to, Climate Change in the Southeast Coast of Bangladesh. Unpublished master's thesis, University of Adelaide, Adelaide, Australia. Accessible at https://digital.library.adelaide.edu.au/dspace/bitstream/2440/99143/2/02whole.pdf.

Hickman, L. (2013, August 28). The era of climate change 'denial' is over. The Guardian. Retrieved from http://www.theguardian.com/environment/blog/2013/aug/28/era-climatechange-denial-over.

Höhne, N., \& Blok, K. (2005). Calculating historical contributions to climate change: discussing the Brazilian Proposal. Climatic Change, 71, 141-173.

Hugo, G. (1996). Environmental concerns and international migration. International Migration Review, 30(1), 105-131.

Hulme, M. (2009). Why we disagree about climate change: understanding controversy, inaction and opportunity. New York, N.Y.: Cambridge University Press.

IPCC. (2014). Climate Change 2014: Impacts, Adaptation, and Vulnerability. Contribution of Working Group II to the Fifth Assessment Report of the Intergovernmental Panel on Climate Change. Retrieved from http://ipccwg2.gov/AR5/images/uploads/WG2AR5_SPM_FINAL.pdf. 
Ives, M. (2016, July 02). A Remote Pacific Nation, Threated by Rising Seas. The New York Times. Retrieved from http://www.nytimes.com/2016/07/03/world/asia/climate-changekiribati.html?_r=0.

Jamieson, D. (2010). Climate change, responsibility, and justice. Science and Engineering Ethics, 16(3), 431-445.

Joakim, E. P., Mortsch, L., \& Oulahen, G. (2015). Using vulnerability and resilience concepts to advance climate change adaptation. Environmental Hazards, 14(2), 137-155.

Johnson, G. (2015, May 11). So far, most atolls winning the sea level rise battle. Pacific Institute of Public Policy. Retrieved from http://pacificpolicy.org/2015/05/so-far-mostatolls-winning-the-sea-level-rise-battle/.

Kelman, I. (2015). Difficult decisions: Migration from Small Island Developing States under climate change. Earth's Future, 3(4), 133-142.

Kibue, G. W., Pan, G., Joseph, S., Xiaoyu, L., Jufeng, Z., Zhang, X., \& Li, L. (2015). More than two decades of climate change alarm: Farmers knowledge, attitudes and perceptions. African Journal of Agricultural Research, 10(27), 2617-2625.

Kiribati National Statistics Office. (2015). Departures by final destination. Retrieved from http://www.mfed.gov.ki/statistics/.

Knight, B. \& Leckie, S. (2015, September 24). Visions from a vanishing atoll. Deutsche Welle. Retrieved from http://www.dw.com/en/visions-from-a-vanishing-atoll/g-18731545.

Korauaba, T. (2015). KIRIBATI. Contemporary Pacific, 27(1), 232-238.

Lee, T. M., Markowitz, E. M., Howe, P. D., Ko, C-Y., \& Leiserowitz, A. A. (2015). Predictors of public climate change awareness and risk perception around the world. Nature Climate Change, 5, 1014-1020. 
Lesnikowski, A. C., Ford, J. D., Berrang-Ford, L., Barrera, M., \& Heymann, J. (2015). How are we adapting to climate change? A global assessment. Mitigation and Adaptation Strategies for Global Change, 20(2), 277-293.

Lowy Institute for International Policy (Lowy Institute). (2015). Australian Foreign Aid: How effective aid is delivering results. Retrieved from http://www.lowyinstitute.org/issues/australian-foreign-aid.

Maibach, E., Myers, T., \& Leiserowitz, A. (2014). Climate scientists need to set the record straight: There is a scientific consensus that human-caused climate change is happening. Earth's Future, 2, 295-298.

Malik, A., \& Lan, J. (2016). The role of outsourcing in driving global carbon emissions. Economic Systems Research, 28(2), 168-182.

Malka, A., Krosnick, J. A., \& Langer, G. (2009). The association of knowledge with concern about global warming: trusted information sources shape public thinking. Risk Analysis, 29, 633-647.

Migration Policy Institute. (2013). Environmental change and migration: What we know. Retrieved from http://www.migrationpolicy.org/research/environmental-change-andmigration-what-we-know.

McAdam, J. (2013, March 15). Caught between homelands. Inside Story. Retrieved from http://insidestory.org.au/caught-between-homelands/.

McLeman, R. A. (2013). Climate and human migration: Past experiences, future challenges. New York, N.Y.: Cambridge University Press.

McNamara, K. E. (2015). Cross-border migration with dignity in Kiribati. Forced Migration Review, 49, 62. 
Melillo, J. M., Richmond, T. C., \& Yohe, G. W. (2014). USGCRP, 2014: Climate Change Impacts in the United States: The Third National Climate Assessment.

Methmann, C., \& Oels, A. (2015). From 'fearing' to 'empowering' climate refugees: Governing climate-induced migration in the name of resilience. Security Dialogue, 46(1), 51-68.

Morss, R. E., Wilhelmi, O. V., Meehl, G. A., \& Dilling, L. (2011). Improving societal outcomes of extreme weather in a changing climate: an integrated perspective. Annual Review of Environment and Resources, 36, 1-25.

Mortreux, C., \& Barnett, J. (2009). Climate change, migration and adaptation in Funafuti, Tuvalu. Global Environmental Change, 19(1), 105-112.).

NASA. (2016). Taking a global perspective on Earth's climate. NASA Global Climate Change. Retrieved from http://climate.nasa.gov/nasa_role/.

Nash, S. (2015). Towards an 'environmental migration management' discourse: A discursive turn in environmental migration advocacy? In K. Rosenow-Williams, \& F. Gemenne, (Eds.), Organizational Perspectives on Environmental Migration, (pp. 198-215). New York, N.Y.: Routledge.

Ni, X-Y. (2015). A nation going under: Legal protection for "climate change refugees". Boston College International \& Comparative Law Review, 38(2), 329-366.

O’Brien, K., Eriksen, S., Nygaard, L. P., \& Schjolden, A. (2007). Why different interpretations of vulnerability matter in climate change discourses. Climate policy, 7(1), 73-88.

Oels, A. (2013). Rendering climate change governable by risk: From probability to contingency. Geoforum, 45, 17-29.

Omeziri, E., \& Gore, C. (2014). Temporary measures: Canadian refugee policy and environmental migration. Refuge, 29(2), 43-53. 
Paavola J., \& Adger, W. N. (2006). Fair adaptation to climate change. Ecological Economics, 56, 594-609.

Pala, C. (2014). Kiribati President Purchases 'Worthless' Resettlement Land as Precaution Against Rising Sea. Inter Press Service News Agency. Retrieved from http://www.ipsnews.net/2014/06/kiribati-president-purchases-worthless-resettlementland-as-precaution-against-rising-sea/.

Pölzler, T. (2015). Climate Change Inaction and Moral Nihilism. Ethics, Policy \& Environment, $18(2), 203-215$.

Porter, J. (2015). Shrinking mobility in soaring temperatures: Understanding the impact of changes in mobility on household adaptive capacity in semi-arid rural northern Ghana. Unpublished master's thesis, Universiteit Ultrecht, Ultrecht, Netherlands.

Purvis, K. (2016, February 15). Sinking states: the islands facing the effects of climate change. The Guardian. Retrieved from https://www.theguardian.com/global-developmentprofessionals-network/gallery/2016/feb/15/pacific-islands-sinking-states-climate-change.

Raleigh, C., Choi, H. J., \& Kniveton, D. (2015). The devil is in the details: An investigation of the relationships between conflict, food price and climate across Africa. Global Environmental Change, 32, 187-199.

Renaud, F. G., Dun, O., Warner, K., \& Bogardi, J. (2011). A decision framework for environmentally induced migration. International Migration, 49(1), 5-29.

Republic of Fiji. (2014). Fiji will support Kiribati as sea level rises. Politics \& Government Business, 31. Retrieved from http://ezproxy.lib.ryerson.ca/login?url=http://search.proquest.com/docview/1500310463? accountid=13631. 
Resurreccion, B. P. (2016). Discourses that hide: gender, migration and security in climate change. In C, Brun, B. Piers, \& M. Jones, (Eds.), Alternative Development: Unraveling Marginalization, Voicing Change (pp. 219-242). New York, N.Y.: Routledge.

Ribot, J., 2011. Vulnerability before adaptation: toward transformative climate action. Global Environmental Change, 21, 1160-1162.

Roman, M. T. (2013). Migration, transnationality, and climate change in the Republic of Kiribati (Order No. 3585502). ProQuest Dissertations \& Theses Global. (1512424304). Retrieved from http://ezproxy.lib.ryerson.ca/login?url=http://search.proquest.com/docview/1512424304? accountid=13631.

Seabrook, J. (2016). How the lifestyle of the rich became anthropogenic activity in the climate change debate. Race and Class, 57(4), 87-94.

Shi, J., Visschers, V. H. M., Siegrist, M., \& Arvai, J. (2016). Knowledge as a driver of public perceptions about climate change reassessed. Nature Climate Change, n.p. Retrieved from http://www.nature.com/nclimate/journal/vaop/ncurrent/full/nclimate2997.html.

Stake, R. E. (1995). The art of case study research. Thousand Oaks, CA: Sage.

Steiner, C. E. (2015). A sea of warriors: Performing an identity of resilience and empowerment in the face of climate change in the pacific. Contemporary Pacific, 27(1), 147-181.

Tacoli, C. (2009) Crisis or Adaptation? Migration and climate change in a context of high mobility. International Institute for Environment and Development, 21(2), 513-525.

Termeer, C., Dewulf, A., van Rijswick, H., van Buuren, A., Huitema, D., Meijerink, S., ... \& 
Wiering, M. (2011). The regional governance of climate adaptation: a framework for developing legitimate, effective, and resilient governance arrangements. Climate Law, 2(2), 159-179.).

Thompson, L. (2016). The nexus in small island developing states. In F. Dodds, \& J. Bartram (Eds.), The Water, Food, Energy and Climate Nexus: Challenges and an Agenda for Action (pp. 149-162). New York, NY: Routledge.

Tonkiss, F. (2004). Analysing Text and Speech: Content and Discourse Analysis. In C. Seale, (Ed.), Researching Society and Culture, (pp. 367-381). Thousand Oaks, CA: Sage. United Nations High Commissioner for Refugees (UNHCR). (2015). Human Mobility in the Context of Climate Change UNFCCC. Paris COP-21: Recommendations from the Advisory Group on Climate Change and Human Mobility.

United Nations Framework Convention on Climate Change (UNFCCC). (2005). Climate change: Small island developing states. Retrieved from http://unfccc.int/resource/docs/publications/cc_sids.pdf.

United Nations Framework Convention on Climate Change (UNFCCC). (2014). First steps to a safer future: Introducing The United Nations Framework Convention on Climate Change. Retrieved from http://unfccc.int/essential_background/convention/items/6036.php.

United Nations Population Fund Pacific Sub-Regional Office (UNFPA Pacific). (2014). Population and Development Profiles: Pacific Island Countries. Retrieved from http://countryoffice.unfpa.org/pacific/drive/web_140414_UNFPAPopulationandDevelo pmentProfiles-PacificSub-RegionExtendedv1LRv2.pdf.

United Nations University Institute for Environment and Human Security (UNU-EHS). (2015). 
Climate Change and Migration in the Pacific: Links, attitudes, and future scenarios in Nauru, Tuvalu, and Kiribati. Retrieved from https://unfccc.int/files/science/workstreams/research/application/pdf/part2_unuehs_oakes_vandergeest_poster.pdf.

Upadhyay, H., Kelman, I., Lingaraj, G. J., Mishra, A., Shreve, C., \& Stojanov, R. (2015). Conceptualizing and contextualizing research and policy for links between climate change and migration. International Journal of Climate Change Strategies and Management, 7(3), 394-417.

US Department of State. (2011). Background note: Kiribati. In Background Notes. US Department of State. Washington, DC. Retrieved from http://go.galegroup.com/ps/i.do?id=GALE\%7CA252740818\&sid=summon\&v=2.1\&u=rp u_main\&it=r\&p=AONE\&sw=w\&asid=feabefdf00c $14637 b 000 f 7 a 25 a b 46 d 62$

United Nations Treaty Collection (UNTC). (2016). Status of Treaties: Paris Agreement. Retrieved from https://treaties.un.org/Pages/ViewDetails.aspx?src=TREATY\&mtdsg_no=XXVII-7$\mathrm{d} \&$ chapter $=27 \&$ clang $=\_$en.

Vanderheiden, S. (2014). Common But Differentiated Responsibility. In J-F Morin, \& A. Orsini, (Eds.), Essential Concepts of Global Environmental Governance, (pp. 31-35). New York, N.Y.: Routledge.

Van Dijk, T. A. (2001). Critical discourse analysis. In D. Schiffrin, P. Tanne \& H. Hamilton (Eds.), The handbook of discourse analysis (pp. 352-371). Malden, MA: Blackwell. Varadarajan, T. (March 19, 2012). The world on a page. Newsweek, 159(12), 8. Retrieved from 
http://go.galegroup.com/ps/i.do?id=GALE\%7CA283074626\&sid=summon\&v=2.1\&u=rp

u_main\&it=r\&p=AONE\&sw=w\&asid=a9ae300bbdf464710fa2cd0a81298d86

Walsh, E. M., \& Tsurusaki, B. K. (2014). Social controversy belongs in the climate science classroom. Nature Climate Change, 4, 259-263.

Weber, E. (2016). Only a pawn in their games? Environmental migration in Kiribati - past, present and future. Journal of the Geographical Society of Berlin 147(2), 153-164.

Weber, S. (2013). Performative vulnerability: climate change adaptation policies and financing in Kiribati. Environment and Planning, 45(11), 2717-2733.

Weiss, K. R. (October 29, 2015a). Before we drown we may die of thirst. Nature, 526(7575), 624-627. Retrieved from http://www.nature.com/news/before-we-drown-we-may-die-ofthirst-1.18652.

Weiss, K. R. (2015b). EXILE BY ANOTHER NAME. Foreign Policy, (210), 48-56. Retrieved from http://ezproxy.lib.ryerson.ca/login?url=http://search.proquest.com/docview/1655003212? accountid=13631.

Weiss, K. R. (March 10, 2015c). Leader of island nation advocates exit strategy for rising seas. National Geographic. Retrieved from http://news.nationalgeographic.com/2015/03/150310-pacific-atoll-kiribati-anote-tongclimate-change-rising-seas/.

Weisslitz, M. (2002). Rethinking the Equitable Principle of Common but Differentiated Responsibility: Differential Versus Absolute Norms of Compliance and Contribution in the Global Climate Change Context. Colorado Journal of International Environmental Law and Policy, 13(2), 473-496. 
Wells, D. (2014). Climate change discourse: Critical implications for small island developing states. Columbia University Coalition for Sustainable Development. Retrieved from http://www.columbiasd.org/climate-change-discourse-critical-implications-for-smallisland-developing-states/.

Wise, R. M., Fazey, I., Smith, M. S., Park, S. E., Eakin, H. C., Van Garderen, E. A., \& Campbell, B. (2014). Reconceptualising adaptation to climate change as part of pathways of change and response. Global Environmental Change, 28, 325-336.

World Bank Group. (2008). World Development Indicators Database. Retrieved from http://publications.worldbank.org/WDI/indicators.

World Economic Forum. (2016). Insight Report: The Global Risks Report 2016. $11^{\text {th }}$ Edition. Retrieved from http://www3.weforum.org/docs/Media/TheGlobalRisksReport2016.pdf.

Wyman, K. M. (2013). Responses to Climate Migration. Harvard Environmental Law Review $37(1), 167-216$.

Yarris, K., \& Castañeda, H. (2015). Special Issue Discourses of Displacement and Deservingness: Interrogating Distinctions between "Economic" and "Forced" Migration. International Migration, 53(3), 64-69.

Zellentin, A. (2015). Climate justice, small island developing states \& cultural loss. Climatic Change, 133(3), 491-498. 